\title{
III. On earthquake-sounds
}

\section{Charles Davison Sc.D. F.G.S.}

To cite this article: Charles Davison Sc.D. F.G.S. (1900) III. On earthquake-sounds, Philosophical Magazine Series 5, 49:296, 31-70, DOI: 10.1080/14786440009463823

To link to this article: http://dx.doi.org/10.1080/14786440009463823

$$
\text { 册 Published online: } 21 \text { Apr } 2009 .
$$

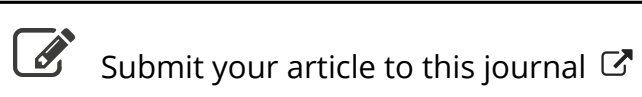

\footnotetext{
Џll Article views: 4
}

Q View related articles $\asymp$ 
and 3 per cent. This seems to show that in the cases of some sheets of hard rubber, the thermal conductivity of the skin near the polished surfaces is somewhat less than that of the inass of the material in the sheet. This difference, however, is too slight to account for the differences of conductivity shown by the table. It is well to emphasize the fact that the specific heat between $25^{\circ} \mathrm{C}$. and $100^{\circ} \mathrm{C}$. of the standard rubber is less $(0 \cdot 339)$ than that of such thin sheet rubber as I have experimented upon.

Stefan found for the thermal conductivity of a certain sheet of rubber, 0.787 centim. thick, the value 0.00026 : this rubber had a somewhat greater density $(\mathbf{1} \cdot 22)$ and a much lower sperific heat $(0 \cdot 23)$ than any of iny specimens, so that the ratio of the conductivity to the specific heat per unit volume was somewhat greater. Experimenting upon a small disk of "ebonite" 1.93 centim. in diameter and 0.0414 centim. thick, Lees found the conductivity to be 0.00040 .

The Jefferson Physical Laboratory,

Harvard University, Cambridge, U.S.A.

\section{On Earthquake-Sounds. $B y$ Charles Davison, Sc.D., F.G.S.*}

IN a short paper published seven years ago $\dagger, I$ attempted 1 to describe the phenomena of earthquake-sounds and to offer a theory of their origin. More detailed studies of recent British earthquakes, and especially of the Hereford earthquake of 1896, have added to our knowledge of the phenomena and slightly modified the theory. The catalogues of foreign seismologists have also furnished materials for investigation. I propose therefore to reconsider the subject in the present paper, dwelling chiefly on those points which have not yet received much attention.

\section{General Character of the Sound.}

The earthquake-sound is frequently described simply as a rumbling sound or, more fully, as a hollow or muffed rumbling sound, a harsh grumbling sound, a mysterious suppressed roar, or a strange deep sort of groan or moan. Occasionally, sounds of a totally different kind are observed, either alone or in conjunction with the preceding, sounds that are described by the terms rustling, whizzing, or hissing. The sound is generally of a more or less jarring nature, hardly ever becoming a musical tone, although it may approach to

* Communicated by the Author.

† "On the Nature and Origin of Earthquake-Sounds": Geol. Mag. vol. ix. 1892, pp. 208-218. 
such a character, as is evident from the comparisons to the deep notes of an organ, \&c. The references to distant thunder and the moaning of the wind also testify to a certain smoothness or monotony in the sound. To some observers, however, the sound appears to be intermittent, to be like three loud explosive moans, or successive discharges of cannon, or a heavy body falling several times, say, down a short flight of stairs.

At places near the epicentre, the loudness of the sound is one of the chief features of a moderately strong earthquake. The sound is compared to the rumbling of six traction-engines, to that of a train going over a bridge, only intensified a hundred times, to a tremendous roaring, a sudden loud deafening noise, or a terrific explosion, louder than is produced by the heaviest artillery. Even in so slight an earthquake as that felt in the south of Cornwall on April 1, 1898, one observer described the sound as like the rumbling of thirty or forty waggons travelling at a rapid pace, while another remarked " that was the loudest thunder I ever heard." This may almost appear to be the language of exaggeration ; but, from a careful study of the evidence, I think that it expresses the experience of certain, but not of all, observers. It will be seen afterwards how widely persons differ in their powers of hearing earthquake-sounds.

Another prominent characteristic of the sound is its extraordinary depth. The rolling of heavy railway-trucks, very low, is the evidence of one observer ; of another, a low rumbling sound, much lower than the lowest thunder; while a third refers to the vibrations of the podal notes of a great organ, only of a deeper pitch than can be taken in by the human ear. The idea of great depth is also given by the very frequent use of the word "heavy"*. It is applied in every type of comparison, sometimes in an unusual manner, as, for example, in heavy thunder, a heavy conflagration, or a heavy explosion.

The earthquake-sound is frequently compared to the passing of heavy waggons and other vebicles. The comparison seems to be generally suggested when the sound is of long duration, of a certain smoothness, and gradually increases in intensity to a maximum and then dies away $\dagger$. The reference is often

* In strong earthquakes, the percentage of descriptions in which the word "heavy" occurs, varies from 28 in the Hereford earthquake of 1896 to 45 in the Pembroke earthquake of 1893 . In very slight earthquakes it may fall as low as 13.

$t$ In the Leicester earthquake of 1893,27 observers stated that the sound gradually increased in intensity and then died away; and of these 20 compared the sound to that of passing vehicles. 
to a vehicle driven quickly past, to illustrate apparently the evenness of the sound or the rapidity with which it attains and recedes from its maximum intensity. The common illusion that an underground train rushes up to and beneath a house, and continues its journey in the opposite direction, is no doubt due to this gradual rise and fall in intensity.

\section{Types of Earthquake-Sound.}

A few observers find it difficult to describe the sound, but most compare it to some well-known type, and the resemblance in many cases is so close that the observer at first attributed it to the object of comparison. The descriptions which I have examined, several thousands in number, may be classified under the following heads :-

(1) Waggons \&c. passing.--One or several traction-engines, either alone or heavily laden, sometimes driven furiously past; a steam-roller travelling at a quicker pace than usual or passing over frozen ground; heavy waggons coming quickly down a hill, driven over stone paving, on a hard or frosty road, in a covered way or narrow street, or over hollow ground or a bridge; a heavy roller on a garden path, or a wheelbarrow on a hard and frosty road; express or beavy goods trains rushing tbrough a tunnel or a deep cutting, crossing a wooden bridge or iron viaduct, or a heavy train running on snow; also, the dragging of heavy furniture or boxes across an adjoining floor, the grating of a boat on a beach or of the bottom of a large vessel when dragged over rocks.

(2) Thunder.-A loud clap or heavy peal, sometimes dull, hollow, muffled, or subdued, but most often distant, and thus conveying the impression of a low deep booming sound.

(3) Wind.-A moaning, roaring, howling, rushing, hissing, or rough, strong wind ; the rising of the wind, the roaring of a great squall, a heavy wind pressing against the house, or a high wind sweeping through trees; the howling of wind in a chimney, a chimney on fire, and the blare of a furnace when the door is opened.

(4) Loads of stones \& c. falling.-The tipping of a load of coal, stones, or bricks ; a wall or roof falling, or the crash of a chimney through the roof.

(5) Fall of heavy bodies. - The fall of a heavy weight, of a tree or heavy timber; the thud of a large mass of snow from a house-top, the banging of a door, only more muffled, and the blow of a wave on the sea-shore.

(b) Explosions. - The explosion of a boiler, a cartridge of Phil. Mag. S. 5. Vol. 49. No. 296. Jan. 1900. 
lynamite, or a rocket; a distant colliery explosion; distant heavy rock-blasting, and the boom of a distant cannon.

(7) Miscellaneous. - The trampling of many animals, such as cows rushing on the turf below, a quick stampede of a large herd of clephants, a number of powerful men struggling desperately in the room overhead; an immense covey of partridges or a flock of starlings on the wing; the roar of a waterfall, the heavy rumbling of sea-waves in a cave, and the breaking of waves on a pebbly beach ; the passage of a party of skaters, the falling of fine rain or hail on the leaves of trees, a low pedal note on the organ; and the rending or settling together of huge masses of rock.

Frequency of Comparison to different Types.-The type of comparison employed varies not only in different earthquakes, but in different parts of the disturbed area of one and the same earthquake. This is shown by Table I., in which the figures denote the percentage of entries under each type with regard to the total number of comparisons.

TABLE I.

\begin{tabular}{|c|c|c|c|c|c|c|c|c|}
\hline Earthquake. & 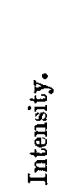 & 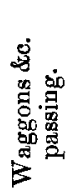 & & 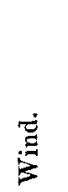 & 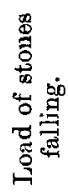 & 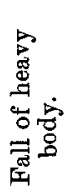 & 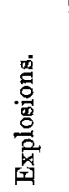 & 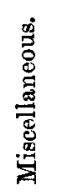 \\
\hline Cornwall, May 17, 1892 . & 4 & $22 \cdot 7$ & $22 \cdot 7$ & $\ldots$ & $6 \cdot 8$ & $2 \cdot 3$ & $43 \cdot 1$ & $2 \cdot 3$ \\
\hline,$\quad$ Aug. $27,1895 \ldots$ & 4 & 334 & $46 \cdot 7$ & $\ldots$ & $\ldots$ & $\ldots$ & $20 \cdot 0$ & $\ldots$ \\
\hline Jan. $26,1896 \ldots$ & 3 or 4 & 267 & $56 \cdot 7$ & & & & 167 & \\
\hline " Apr. $1,1898 \ldots$ & 4 & $25 \cdot 0$ & $36 \cdot 4$ & $5 \cdot 7$ & 23 & $2 \cdot 3$ & 239 & $4 \cdot 5$ \\
\hline Hereford, Oct. $6,1863 \ldots$ & 8 & $37 \cdot 4$ & $25 \cdot 7$ & $7 \cdot 6$ & $2 \cdot 9$ & $6 \cdot 4$ & $12 \cdot 8$ & $7 \cdot 0$ \\
\hline Essex, Apr. 22, $1884 \ldots \ldots$ & 8 & $40 \cdot 0$ & 3200 & 16.0 & 4.0 & & $8 \cdot 0$ & \\
\hline Inverness, Nov, $15,1890 \ldots$ & 7 & $62 \cdot 3$ & $10 \cdot 0$ & $7 \cdot 8$ & 33 & $5 \cdot 6$ & $8 \cdot 9$ & $2 \cdot 2$ \\
\hline Pembroke, Aug. 18, 1892... & 7 & $44 \cdot 5$ & $29 \cdot 0$ & 67 & $2 \cdot 2$ & 1.8 & 49 & $11 \cdot 1$ \\
\hline Leicester, Aug. 4, 1893 ... & 5 & $51 \cdot 1$ & $33-7$ & & 22 & 1.6 & $9 \cdot 2$ & $2 \cdot 2$ \\
\hline Pembroke, Nov. $2,1898, \ldots$ & 7 & 51.0 & $20 \cdot 4$ & $6 \cdot 0$ & 32 & $3 \cdot 2$ & $8 \cdot 8$ & $7 \cdot 4$ \\
\hline Exmoor, Jan. 23, $1894 \ldots$ & 4 & $40 \cdot 5$ & $43 \cdot 2$ & $5 \cdot 4$ & & $2 \cdot 7$ & $5 \cdot 4$ & 27 \\
\hline Hereford, Dec. 17, $1896 \ldots$ & 8 & $45 \cdot 4$ & $15 \cdot 0$ & $15 \cdot 5$ & $3 \cdot 9$ & $2 \cdot 7$ & $7 \cdot 2$ & $10 \cdot 3$ \\
\hline
\end{tabular}

The four Cornish earthquakes were all weak and originated in foci of comparatively small linear dimensions. The Exmoor earthquake, though not much stronger, resembled the remaining shocks in having a long focrs. In these cases, reference is made more frequently than in the first to passing waggons \&c. and less frequently to explosions and the firing of heary guns. Again, in the Comrie earthquakes of 1839 , the sound which accompanied the more violent shocks appeared "to resemble thunder more than 
anything else,-certainly much deeper toned and more awful," while that which was heard with the weaker and shorter shocks was compared to "the noise caused by the blasting of a soft rock at a considerable distance, followed by the reverberation of the surrounding mountains." The type of comparison employed therefore depends on the duration of the sound, and this again on the length of the seismic focus.

\section{Variation in the Nature of the Sound.}

Variation in Intensity.--Even if there were no definite reports on this point, it would be evident, from the frequent references to passing vehicles, that the sound is often of varying intensity. Sometimes the sound becomes gradually louder and ceases almost abruptly, or it may begin suddenly and die away gradually; but in these cases the more or less rapid termination is probably subjective and due to the observer's inability to hear deep sounds. In each of the three most important British earthquakes of the last decade (namely, the Pembroke earthquakes of 1892 and 1893, and the Hereford earthquake of 1896), more than 90 per cent. of the observers who refer to the point distinguish some change in the intensity of the sound; while the percentages of those who heard the sound becomo gradually londer and then die away are respectively 68,85 , and 56 .

The relation which the change in intensity of the sound bears to that of the shock is important. Generally, the two increase and decrease together, though, as will be seen afterwards, there are exceptions to this statement. Or, when the shock is slight, it is folt when the sound is loudest, as at Helston, during the Cornwall earthquake of May 17, 1892, when "a distant rumble was heard, gradually increasing in intensity until it became a violent thundering sound, at which instant everything in the room was perceptibly shaken, the sound dying away with the shock with the same sound as before" ".

Variation in Character.-As a general rule, the sound adheres throughout to one of the types enumerated above, and varies, if at all, only in intensity. In the neighbourhood of the epicentre, however, there is also a change in character perceptible to some, but not all, observers, the change taking

* Mr. David Milne (Edin. New Phil. Journ. vol. xxxi. 1841, p. 261) remarks that, in British earthquakes, there may be two perfectly distinct sensations, a tremulous motion, and a violent blow or concussion. "The tremulous or trembling motion," he says, " is always perceived. When the blow occurs, it is generally in the midst of the tremors, and accompanied with the loudest noise." 
place at the time when the shock is strongest. It then assumes a rougher, more grinding or grating character, occasionally, but not often, being heard as a loud report or crash. As this is a feature which does not seem to have attracted much attention, the following examples from different British earthquakes are given in illustration.

At Penryn, the Cornwall earthquake of 1892 consisted of two distinct vibrations, each followed by tremulous motion; each was also accompanied by a sound like the crash of a heavy weight on the floor above and followed by a rumbling sound like that of a waggon roaring along the street, continuing after the shock and dying away in the distance. At Lamphey, during the Pembroke earthquake of 1892, a sound was heard for three seconds resembling that of sea-waves at a distance, followed for two seconds by a deep heavy boom of thunder, during which the shock was felt, and this by a sound like sea-waves dying away in about three seconds.

Many observations of this kind were made during the Hereford earthquake of 1896. For instance, at Dilwyn in Herefordshire, there was a rumbling as of a train going over a bridge, with a terrific crash, such as is heard in a thunderstorm, at the instant when the shock was strongest, the rumbling dying away afterwards for some seconds. Again, at Horsley in Gloucestershire, the sound was first like a violent wind among trees; then, while the shock lasted, like a very heavy traction-engine close to the house, and, at the instant when the sound was loudest and the shock strongest, the rumbling was accompanied by a sort of grinding noise, which appeared to be under the observer's house, and sounded as if a landslip was in progress.

When the sound is compared to wind, a change is frequently observed. Thus, Prof. Papavasiliou records, on the anthority of M. de Biasi, that a strong shock felt in Zante on June 31 (sic), 1896, ' fut précédée d'un bruit pareil d'abord à celui du vent, puis à celui d'une voiture"; and a similar change was observed in the same island on Sept. 23, $1896 *$. During the Hereford earthquake of 1896, the change generally took place at or about the instant when the shock began or ceased to be felt; as at Batley, in Yorkshire, where the shock was preceded by a sound as of a rushing wind, and was accompanied by a low rumbling noise like distant thunder.

Though some exceptions to the conclusion will be noticed later, it thus appears that, as an earthquake-shock increases 1896 ,

* Observatoire National d'Athènes, Bull. Mens. Séismol. 1 année, 
and decreases in intensity, the sound grows louder and dies away, and also deepens and rises in pitch ; in other words, the vibrations which are observed as shock and sound increase and decrease together in amplitade and period.

\section{Variation in the Nature of the Sound throughout the Disturbed Area.}

In one respect the sound exhibits a marked uniformity all over the sound-area, namely, in its great depth, if we may, judge from the frequency with which the word "heavy", occurs in the descriptions. In the Hereford earthquake, the word is used in 27 per cent. of the comparisons from the seven central counties, in 30 per cent. from the counties surrounding these, and in 27 per cent. from those which lie outside. In the Pembroke earthquake of 1892, the corresponding percentages are 38, 45 , and 31 , and in that of 1893 they are 51,37 , and $39 *$.

Variation in Type.-The connexion between frequency of type-reference and distance from the epicentre is shown roughly in the Table (p. 38).

'The principal change common to all three earthquakes is thus the increasing percentage with the distance of the comparisons to wind; and we may infer from this that the sound tends to become smoother and more nearly monotonous as we recede from the epicentre. As a rule, the comparisons to passing waggons \&c. are less numerous at a distance than near the epicentre. The reasons for this appear to be that the duration of the sound diminishes as the distance increases, and that the rise and fall in intensity are also less marked. In the Hereford earthquake it is possible to draw curves of equal percentage of reference to this type, and these show that the frequency of reference depends on the duration of the sound.

Variation in Change of Intensity.-One effect of distance would naturally be to quench the weaker sound-vibrations at the beginning and end, and we should expect to find less variation in the intensity of the sound at a distance than near

* In the Hereford earthquake, the central counties are those of Hereford, Gloucester, Worcester, Shropshire, Radnor, Brecon, and Monmouth ; the inner ring consists of Somerset, Wiltshire, Berkshire, Oxford, Warwick, Birmingham, Stafford, Cheshire, Flint, Denbigh, Montgomery, and Glamorgan; and the outer ring of the remaining counties in which the sound was heard. In the Pembruke euthquakes the central counties are Pembroke, Carmarthen, and Cardigan; thuse in the inner ring are Cornwall, Devon, Glamorgan, Brecon, Radnor, Montgomery, and Merioneth; while the outer ring consists of the remaining counties of the sound-area. 
Dr. C. Davison on Earthquake-Sounds.

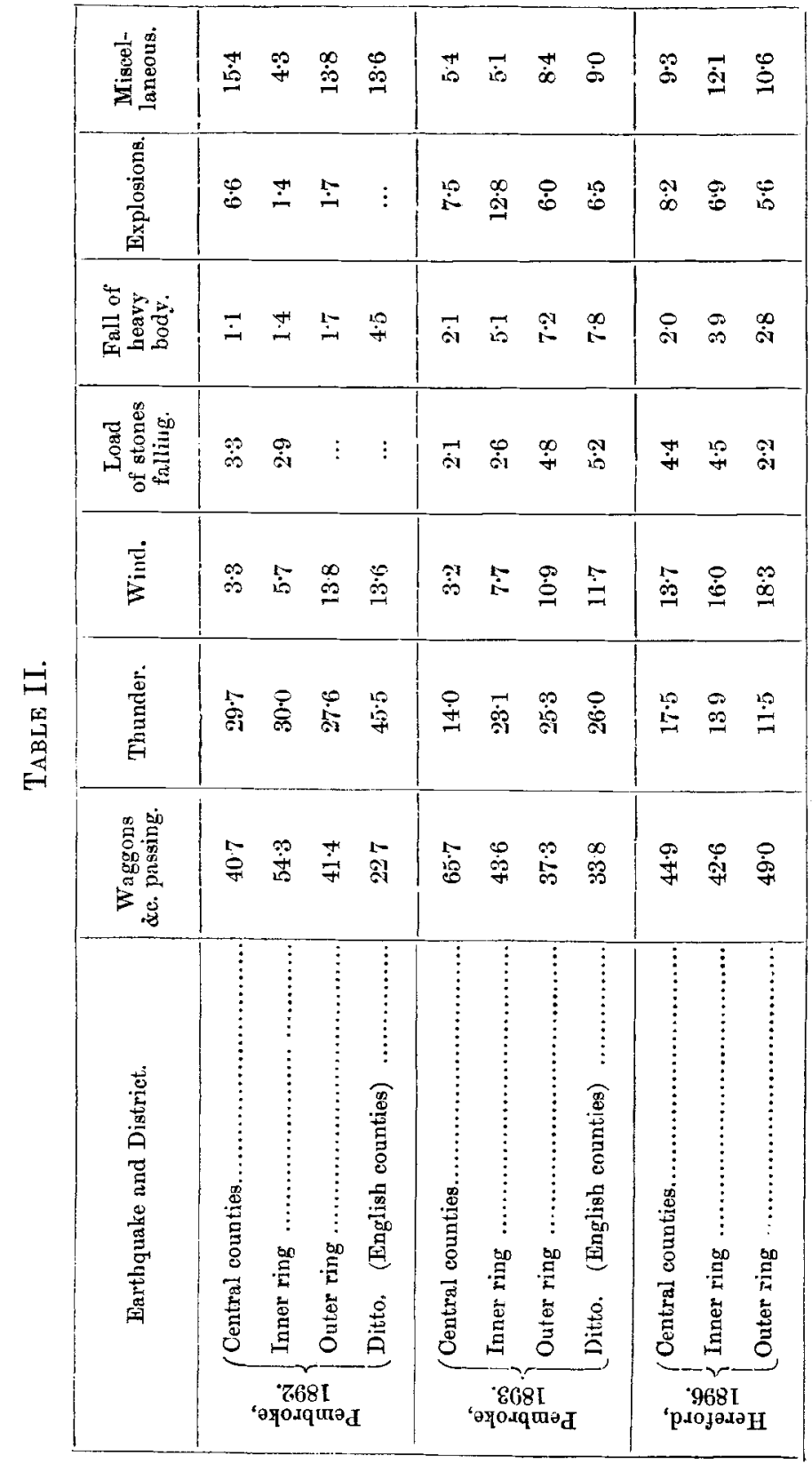


the epicentre. This certainly is the case, but the change is not a marked one; for, in the Hereford earthquake, of all the observers who refer to the point, the percentages of those who heard the sound increase to a maximum and then die away are 57.3 for the central counties, 53.7 for the inner ring, and $53 \cdot 1$ for the outer ring. The corresponding percentages for those who considered the sound of uniform intensity throughout are $8 \cdot 0,11 \cdot 1$, and $12 \cdot 2$.

The test employed, however, is not a very clear one, for at all stations but those near the boundary of the sound-area some change in the intensity would be perceptible. A better test is furnished by the observed nature of the sound, by the increasing frequency of reference to the wind-type as we recede from the epicentre, and by the comparison of the sound at great distances to distant thunder.

Variation in Change of Character.-In the Hereford earthquake, the percentage of the total number of accounts in which any change was recorded is 19.4 in the central counties, 10.7 in the inner ring, and 2.8 in the outer ring, of counties. In the first district the change of type is generaily due to the perception of the crashing or grinding sound which accompanied the strongest vibrations; in the others, the change, when observed, is almost invariably from a sound like wind to a more rumbling sound at the time of the shock, or vice versâ. In every earthquake I have studied, it is only near the epicentre that the explosive reports or crashes in the midst of the rumbling sound are heard. At a moderate distance, the sound before and after the shock becomes smoother, while the sound which accompanies the shock retains to a certain extent its rougher and more rumbling character. As we approach the boundary of the disturbed area, the irregularities are still further sinoothed away, and the only sound heard is like the low, almost monotonous roll of distant thunder.

\section{Variability in the Sound due to its Neighbourhood to the Lower Limit of Audibility.}

Inaudibility to some Observers.--Attention has been drawn in the preceding pages to the extraordinary depth of the earthquake-sound, so far as it can be inferred from the efforts that are made to describe it. But the most decisire evidence of the close neighbourhood of the sound to the lower limit of audibility is furnished by the fact that the same vibrations are heard by some and not by others. One observer will describe the sound as like the rumbling pro 
duced by a heavy traction-engine passing, while another will be equally positive that the shock was unaccompanied by sound. Not only people in the same town, but persons in the same house, and even in the same room, differ in this respect. There is no reason, it should be remarked, for supposing that they were not equally alert, or that their conditions varied essentially except in their powers of perceiving deep sound.

This point is so important that I venture to give further evidence in illustration.

M. Ch. Deville, who studied the Guadeloupe earthquake of Feb. 8, 1843, remarks that “ce bruit . . . n'est pas perçu par tout le monde. Ni moi, ni les personnes qui m'entouraient, ne l'avons entendu à la Dominique; bien plus, peutêtre par suite de l'émotion, une foule de témoins du désastre de la Pointe-à-Pitre disent ne l'a voir point entendu. Quelques uns afferment, au contraire, que ce bruit s'est prolongé un petit nombre de secondes encore après la commotion; pour d'autres, il a été sensible dans quelques unes des secousses de moindre violence qui se sont succédé depuis celle du 8. On prétend même que chacune de ces dernières est annoncée par un bruit souterrain dans les îlets de la rade de la Pointe-à-Pitre" *.

"In the Tokio seismic area," says Prof. Milne, "sounds accompanying earthquakes are rare. Although the author has observed many earthquakes when sounds are said to have been heard, it has only beerı once during a period of several years that he can say that he distinctly heard a sound. This was on March 11th, 1881, when a sound between hissing and rumbling was heard " $t$.

During the Hereford earthquake of 1896, if we take the evidence only of those observers who were awake before it began, we find that two out of five observers at Clifton did not hear the sound, at Leamington two out of six, in Birm. ingham and the neighbourhood four out of 23 , in London eight out of 18 , and at Bangor two out of seven. In the whole disturbed area, 148 persons who were awake heard no sound, and all but five of these were within the boundary of the sound-area.

Partial Inaudibility to some Observers.-Similar evidence is afforded by the partial inaudibility of the sound, by its total cessation, generally during the shock itself, to some observers, while others continue to hear it. In Great Britain

* Observations sur le tremblement de terre eprouvé à la Guadeloupe le 8 février 1843 (Basse-Terre, 1843), p. 4.

† Japan Seismol. Soc. Trans. vol. Xil. 1888, p. 56. 
records of this kind occur in many earthquakes. For instance, during the Hereford earthquake $8 \frac{1}{2}$ per cent. of the observers who were certainly awake, and heard the sound, state expressly that they were unconscious of any sound while the shock lasted. Generally it was heard only before the shock, ceasing either gradually or somewhat abruptly about the time when the shock began; but it was sometimes heard only when the shock was dying away, and in two cases before and after, but not during, the shock. That this cessation of the sound was inherent in the observers and not due to their position, is evident from the experiences of others in the same places. At Presteign, in Radnorshire, to one obsurver the sound ceased before the vibrations commenced; to another the sound was terrible, as of rending rocks beneath his feet, and was loudest at the time when the shock was strongest. At Birmingham one observer heard the sound befure, during, and after the shock, another entirely before it, a third only after it, while others, as already remarked, heard no sound at all.

Variability in the Nature of the Sound.-Even when observers in the same place agree in hearing the sound, it may present itself to them under different forms. In the Hereford earthquake we find that at Hereford a crash or bomb-like explosion was noticed during the rumbling sound by four observers, while four others describe the sound in terms which imply uniformity of character. At Pridewoud (four miles from the epicentre) one observer, who felt two series of vibrations and heard a loud crash with the maximum of each, remarks that only a few heard this peculiar sound, although most persons noticed a premonitory rumbling. At Ledbury the sound, according to one, began like a rushing wind, and culminated in a loud explosive report; another heard a noise like distant thunder, which ended when the shock began; while a third heard no sound at all. The same diversity, both in character and intensity, is noticeable at places further away from the epicentre. At Clifton one person heard a slight rumbling noise, while another compared the sound with that of a heavy traction-engine passing. In the Birmingham district the accounts refer on the one hand to the distant approach of a train and the rising of the wind, on the other to the reports of large cannons and to a noise as if tons of debris had been hurled against the wall of a house.

Explanation of the above Phenomena.-These observations show clearly that there is a lower limit of audibility, and, further, that this limit is not the same for all persons. Now, to create an equally strong impression on the ear, the 
strength of the vibrations must be very much greater for deep sounds than for high ones, and this is especially the case for the deepest sounds of all. If, then, the sound is just audible to any person, it will cease to be heard if the period of the vibrations be increased without any change occurring in their strength, or if the strength be diminished, while the period remains unchanged.

In the immediate neighbourbood of the epicentre, the sound-vibrations are of such intensity that they are heard by nearly all observers, at any rate in Great Britain. As we recede from the epicentre the vibrations diminish in strength, and at the same time, as we know from seismographic records, the larger vibrations increase in period. On both accounts, then, they tend to become inaudible. Thus the percentage of persons who hear the sound should diminish as the distance from the epicentre increases, until we reach the boundary of the sound-area where no human being is capable of hearing so deep a sound.

If the vibrations which reach a particular observer are at first very rapid, and then gradually increase in period without an appropriate concomitant increase in strength, the sound will become gradually deeper, and finally will cease to be heard, the ending being more or less abrupt. Again, if the period were to be subject to a succession of changes without the proper change of strength, it is possible that to some observers the vibrations might be inaudible during short intervals when the period is great, and they would then hear the sound as a succession of reports, a series of footfalls, \&c.

Further, the vibrations which reach the observers in ono place at any moment are probably of various amplitude and period. One may hear many vibrations, and another only some of the series. Thus to one observer the sound may be like a rising wind, to another like a heavy traction-engine passing; one may hear the crashes which accompany the principal vibrations, while a second will be deaf to them ; to one the sound may become continually louder and cease abruptly, to another it may increase to a maximuin and then gradually die away.

As we recede from the epicentre, however, the vibrations of every period tend to become inaudible. The limiting vibrations of the whole series will be the first to be lost, especially those of longest period. Thus near the epicentre sound-vibrations of many different periods will be heard, and the sound will be more complex than it is elsewhere. It is only in this region that the loud crashes will be heard with the strongest vibrations. As the observer recedes from the 
epicentre these changes in character must become gradually less marked, until at a great distance, near the boundary of the sound-area, the audible vibrations lie within very narrow limits with regard to period, and the sound becomes an almost monotonous deep growl of nearly uniform intensity.

\section{Isacoustic Lines.}

An isacoustic line may be defined as a line which passes through all places in which the percentage of persons who hear the sound is the same.

The construction of isacoustic lines depends on the following principles:-(1) at most places within the sound-area the sound lies between the extreme values of the lower limit of audibility, so that it is heard by some and not by others; $(2)$ as the distance from the centre increases the audibility of the sound-vibrations diminishes, so that the sound is heard by a decrensing proportion of observers ; (3) the people in any district possess various powers of hearing low sounds, but in any one country the percentage of its inhabitants who are capable of hearing a given low sound is probably in all parts very nearly the same.

In fig. 1 (p. 44) the continuous lines represent the isacoustic lines of the Hereford earthquake of 1896 . Their construction depends on the percentage of observers within each county who recorded their perception of the sound. The percentage varies from 87.2 in Herefordshire to 23.1 in Essex, and for any county it is supposed to correspond to that of a small district inmediately surrounding its centre, and for adjoining counties to vary uniformly from one centre to another. 'The counties are of course too large and also too unequal in area to allow of great accuracy in the construction of the lines, and the number of observations in some of the counties at a distance from the epicentre is not so great as is to be desired ${ }^{*}$.

* The inner isoseismal lines of this earthquake are elongated ovals with their longer axes nearly north-west and south-east; and the peculiar form of the isacoustic lines is due to the fact that there were two distinct foci arranged along a north-west and south-east line, the north-west focus (near Hereford) being first in action by a few seconds. The series of vibrations from the two foci coalesced and formed one series at places within a hyperbolic band, the curvilinear axis of which coincides very nearly with the dotted line (fig. 1) passing through the points of greatest extonsion of the isacoustic lines. The disturbance was much stronger at the north-west than at the south-east focus, while the inequality between the sound-vibrations from the two foci was inconsiderable. There was therefore no marked distortion of the isuseismal lines in the neighbourhood of the hyperbolic band, while the isacoustic lines are completely diverted from their normal course. 
Audibility of Earthquake-Sounds in different Countries.

While it appears to be the rule in some countries that earthquakes shall be accompanied by sound, in others it

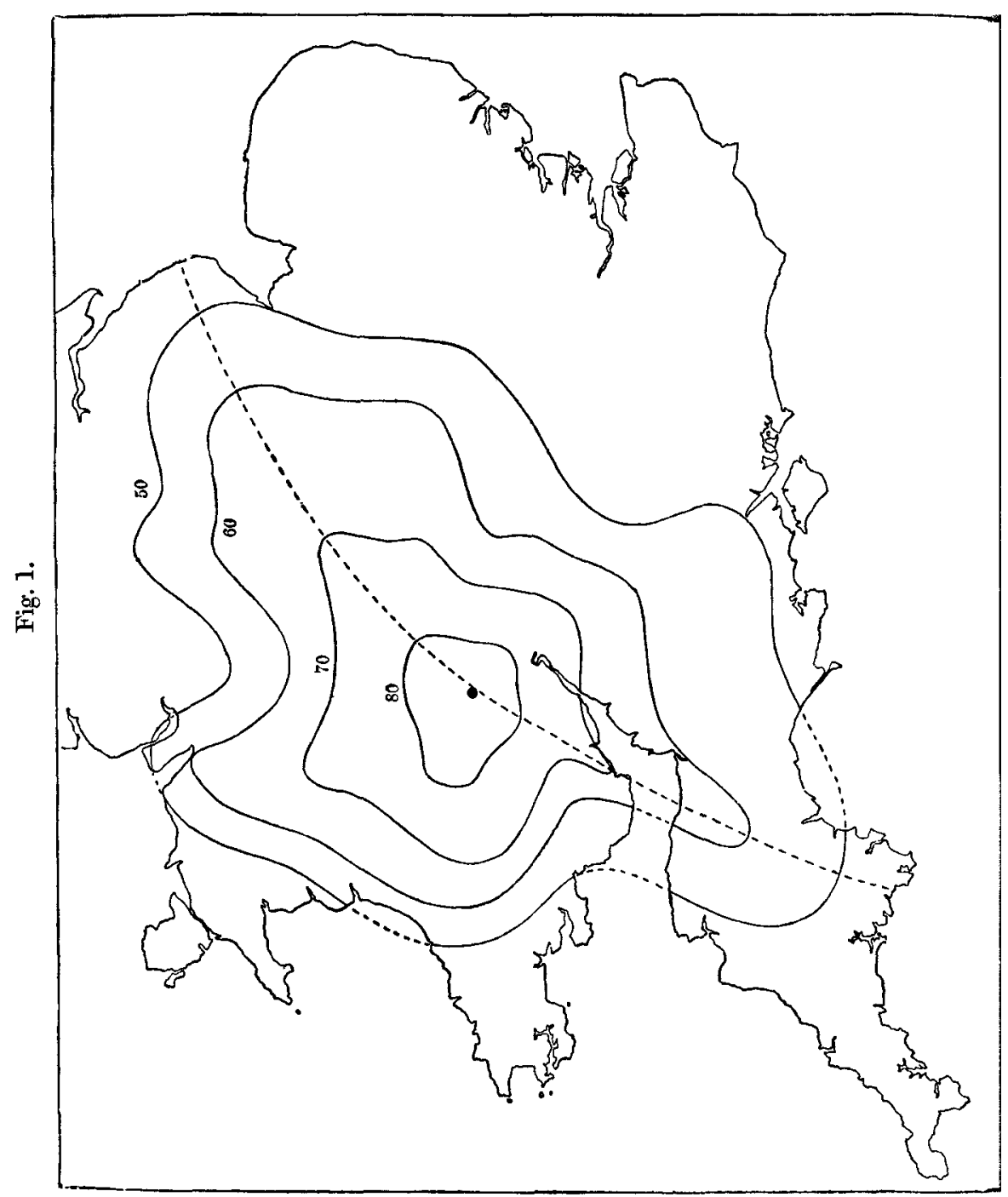

would seem to be rather the exception. The exact percentage of earthquakes attended by sound is, however, difficult to determine, on account of the sligit attention paid 
to sund-phenomena by many compilers of earthquakeeatalogues; so that it often remains uncertain whether we are to attribute the lack of reference to the inaudibility of the vibrations or to the neglect of the compiler or his authorities. For instance, in Barbiani's list of earthquakes in Zante (1825-1863) * only 21 out of 1371 shocks are recorded as accompanied by sound. According to Mr. Roper's cataloguet, only 21 per cent. of the British earthquakes felt during the present century (1801-1889) were attended by sound; but we know from other records that this low figure is chiefly due to incomplete chronicling.

Great Lrituin.-Mr. David Milne, in a valuable memoir on "Earthquake-Shocks felt in Great Britain, \&c.," remarks that "the shocks are invariably accompanied by sounds" $\neq$. Though his list contains many entries in which no mention of sound-phenomena is made, I believe that this statement is practically correct. Among the undoubted earthquakes of the last ten years I know of only one exception. 'The wellknown Comrie earthquakes are hardly, if ever, free from sound ; indeed, the observers speak of "hearing the earthquakes," rather than of feeling them.

\section{TABLE III.}

\begin{tabular}{|c|c|c|}
\hline \multirow{2}{*}{ Earthquake. } & \multicolumn{2}{|c|}{ Percentage of Audibility in } \\
\hline & Disturbed Area. & Central District. \\
\hline Inrerness, $1890 \quad \ldots . \ldots \ldots \ldots \ldots \ldots \ldots . . . . . . . .$. & $93 \cdot 8$ & $\cdots$ \\
\hline Oornwall, $1892, \ldots \ldots \ldots \ldots \ldots \ldots \ldots \ldots \ldots \ldots \ldots \ldots \ldots$ & $95 \cdot 3$ & $\ldots$ \\
\hline Pembroke, 1892, Aug. 18, 0.24 A.M. ... & $75 \cdot 4$ & $97 \cdot 2$ \\
\hline$" \quad, \quad " \quad 1.40$ A.m. ... & $90 \cdot 8$ & $\ldots$ \\
\hline$" \quad, \quad " \quad 2.50$ A.M. ... & $43 \cdot 9$ & ... \\
\hline Leicester, $1893 \ldots \ldots \ldots \ldots \ldots \ldots \ldots \ldots \ldots \ldots \ldots$ & 907 & $\ldots$ \\
\hline 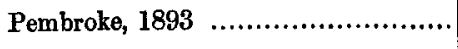 & 58.7 & $98 \cdot 8$ \\
\hline Exmoor, $1894 \quad \ldots \ldots \ldots \ldots \ldots \ldots \ldots \ldots \ldots \ldots \ldots \ldots \ldots \ldots \ldots$ & $100 \cdot 0$ & $\ldots$ \\
\hline Cornwall, $1895 \ldots \ldots \ldots \ldots \ldots \ldots \ldots \ldots \ldots \ldots \ldots \ldots \ldots$ & $100 \cdot 0$ & $\cdots$ \\
\hline,$\quad 1896 \ldots \ldots \ldots \ldots \ldots \ldots \ldots \ldots \ldots \ldots \ldots \ldots \ldots \ldots$ & $100 \cdot 0$ & $\ldots$ \\
\hline Hereford, $1896 \ldots \ldots \ldots \ldots \ldots \ldots \ldots \ldots \ldots \ldots \ldots \ldots \ldots \ldots \ldots$ & $59 \cdot 2$ & $87 \cdot 2$ \\
\hline Cornwall, $1898 \ldots \ldots \ldots \ldots \ldots \ldots \ldots \ldots$ & $93-8$ & $\cdots$ \\
\hline
\end{tabular}

* Dijon, Mén. Acad. vol. xi. 1863, pp. 1-112.

+ 'A List of the more remarkable Earthquakes in Great Britain and Ireland during the Christian Era' By W. Roper (Lancaster, 1889).

$\ddagger$ Edinburgh Now Phil. Journ. vol. xxxi. 1841, p. 287. 
The proportion of observers who hear the sound is generally very great in British earthquakes, as will be seen from Table III. With one exception the percentage is higher for slight than for strong shocks. This of course is partly due to the sound-area in the latter cases being somewhat less than the disturbed area, but not to any great extent, for the number of observers outside the sound-area is always small, It is rather due, I think, to the sound being by far the most prominent feature in a weak earthquake.

Italy.-The organization for the study of earthquakes is more complete in this conntry than in any other except Japan. The results are published by the Central Office of Meteorology and Geodynamics at Rome*. Owing to the uncertainty in some of the time-records, it is not always possible to group together the observations of the same earthquake, and a small error may thus enter into the estimates. In the two years $1895-1896$ the total number of earthquakes (excluding those of distant origin, and others registered only by instruments) is 692 , and of these 217 , or 31.4 per cent., are recorded as accompanied by sound. In different earthquakes the percentage of records in which sound-phenomena are mentioned is very variable, ranging from 18 for the earthquake of June 10,1895 , to 47 for that of April 13, 1895. In the Verona earthquake of June 7, 1891, 34 per cent. of the observers heard the sound. Out of 274 after-shocks of this earthquake, only 25 , or 9 per cent., were attended by sound; and of one of the strongest of these shocks, that of Aug. 31, only five out of $10 \mathrm{t}$ observers were recorded as anditors of the sound $\dagger$.

Admirable as are the observations collected by the Central Office, it is important, from the present point of view, to notice how large a number (more than 60 per cent.) consist of records from single places, through there were often several observers at each place mentioned. The next Table shows the relation between the number of records of each earthquake and the audibility of the accompanying soundphenomena.

This Table shows rery clearly how the audibility of the sound increases with the number of records of the earthquake. It might of course be argued from this that the number of records dep inds on the extent of the disturbed area, and this again on the strength of the shock; in other words, that the sound is more frequently audible with strong, than with

* In supplements to the Boll. della Soc. Sismol. Ital.

+ M. Baratia, Annali dell' Uff. Centr. Meteor. e Geod. vol, xi. parte 3 (1892). 
TABLE I.V.

\begin{tabular}{|c|c|c|c|c|c|c|c|c|}
\hline & \multicolumn{8}{|c|}{ Number of Records. } \\
\hline & 1 & 2 & 3 & 4 & 5 & 6 & $7-10$ & $>10$ \\
\hline \multirow{4}{*}{$\begin{array}{l}\text { Number of earthquakes ...... } \\
\text { Number of earthquakes ac- } \\
\text { companied by sound......... } \\
\text { Percentage of earthquikes } \\
\text { accompanied by sound....... }\end{array}$} & 595 & 91 & 54 & 26 & 13 & 17 & 32 & 45 \\
\hline & & & & & & & & \\
\hline & 124 & 36 & 24 & 15 & 8 & 11 & 26 & 43 \\
\hline & 208 & & $44 \cdot 4$ & & & $64 \cdot 7$ & 812 & $95 \cdot 5$ \\
\hline
\end{tabular}

weak earthquakes. But in Great Britain, at any rate, this is not the case ; for the weaker shocks would often pass entirely unnoticed if it were not for the far greater prominence of the sound. The more probable interpretation is that, with the larger number of records, there is the greater chance of finding among the observers one or more who are capable of hearing very deep sounds. Though the average observer in Italy may be inferior in this respect to the average observer in Great Britain, it is difficult, I think, to resist the conclusion that, with a large enough number of records, every Italian earthquake would be found to be accompanied by sound.

Japan.-For this country we have Prof. Milne's valuable catalogue of 8331 earthquakes recorded between 1885 and $1892^{*}$. Many of the shocks originated beneath the sea, and in the following estimates these have been omitted, for, in some cases, it is possible that the sound-area may not have reached the land. There remain 5902 earthquakes, of which 1562 , or 26.5 per cent., were accompanied by sound.

The percentage varies from year to year, being for the eight years included in the record, $38 \cdot 0,42 \cdot 0,30 \cdot 4,30 \cdot 0$, $33 \cdot 7,20 \cdot 4,20 \cdot 6$, and $29 \cdot 2$ respectively. The low percentages for the years 1890 and 1891 are due to the preponderance of earthquakes in certain districts where the sounds are somewhat rarely heard.

In his great catalogue from which the above results are obtained, Prof. Milne gives approximately the disturbed area and the position of the epicentre of nearly every earthquake. For the latter purpose the whole country is divided into rectangles, the sides of which are a sixth of a degree of latitude and longitude in length. Prof. Milne has studied the distribution of earthquakes accompanied by sound by placing a mark in the epicentral rectangle of each such earthquake. He has shown that the number of these earthquakes

* Japan Seismol. Journ. vol. iv., 1895. 
varies considerably in different districts, and has endeavoured to trace the connexion between the frequency of soundaccompanied earthquakes and the geological structure of the district. I shall refer to these conclusions in the next section.

It is clear, however, that the number of earthquakes accompanied by sound must be a function of the total number of earthquakes, and, therefore, that a better method would be to study the variation in the ratio of the former number to the latter. I have tried to do this for the whole of Japan, but, great as is the number of recorded shocks, it is not sufficient for the purpose ; though a map of a smaller district, in which earthquakes were exceedingly numerous, is given in fig. 2. Taking only those rectangles which contain not less than 20 epicentres during the years $1885-1892$, the percentage of the total number of earthquakes that were accompanied by sound may be as high as 77, and as low as zero. In two rectangles, chiefly affected by the after-shocks of the Kumamoto earthquake of 1889 , the percentage is only 7 .

A point of great importance is the relation between the audibility of an earthquake and its disturbed area. This is shown in Table V.

TABLE V.

\begin{tabular}{|c|c|c|c|c|c|c|c|}
\hline & \multicolumn{6}{|c|}{ Disturbed Area in square miles. } \\
\cline { 2 - 6 } & $<100$ & $100-$ & $500-$ & $1000-$ & $2000-$ & $5000-$ & \\
& 1000 & 2000 & 5000 & 10,000 & $>10,000$ \\
\hline $\begin{array}{c}\text { Number of earthquakes } \\
\text { Number of earthquakes } \\
\text { accompanied by sound }\end{array}$ & 1848 & 2169 & 672 & 403 & 308 & 195 & 218 \\
$\begin{array}{c}\text { Percentage of earthquakes } \\
\text { accompanied by sound }\end{array}$ & $12 \cdot 1$ & $25 \cdot 6$ & $24 \cdot 3$ & $39 \cdot 7$ & $51 \cdot 3$ & $67 \cdot 7$ & $70 \cdot 2$ \\
\hline
\end{tabular}

If we omit the years 1890-1892, on account of the large numbers of aftershocks of the Kumamoto and Mino-Owari earthquakes that were unaccompanied by sound, the corresponding percentages are

$$
25 \cdot 9,24 \cdot 4,41 \cdot 7,45 \cdot 5,62 \cdot 9,69 \cdot 8 \text {, and } 59 \cdot 7 \text {. }
$$

Thus we sre that, with some comparatively unimportant exceptions, the audibility of an earthquake increases with its disturbed area, that is, roughly, with its intensity. But the 
most important fact brought out by this analysis is that the highest percentage is only 70 . The continual approach towards a percentage of 100 , which is characteristic of Italian earthquakes, is here absent. That in eight years as many as 65 earthquakes should disturb areas of more than 10,000 square miles and yet be unaccompanied by recorded sound, while the audibility increases as a rule with the disturbed area, is indicative, in all probability, of the defective powers for hearing deep sounds possessed by the Japanese people*.

Other Countries.-The evidence for other countries is much less complete than in the preceding, and I will therefore merely give a few examples. Of 521 Greek earthquakes in 1896 recorded by Dr. S. A. Papavasiliou, 160 , or $30 \cdot 7$ per cent., were accompanied by sound. Of these, 309 were felt in the island of Zante, and 101 , or 32.7 per cent., of these were attended by sound $\dagger$. Of 39 earthquakes recorded in New Zealand in 1891 , sound was heard with 18 , or 46 per cent. $\neq$. In the Charleston earthquake of 1886 the audibilitypercentage is low in nearly every State, being 19.5 in the central State of South Carolina, and, among the neighbouring States, $21 \cdot 2$ in Virginia, 30.8 in North Carolina, 17.9 in Tennessee, 20.5 in Georgia, 12.5 in Alabama, and 23.0 per cent. in Florida; but it is possible that these low figures are due to the incompleteness of the records \$. The most reliable records for any non-British earthquake are probably those which are obtained from Prof. F. Suess's study of the Laibach earthquake of April 14, 1855 . In this case the audibilitypercentage is 60.8 for the whole disturbed area, and $96^{\circ} 7$ for the central province of Carinthiall.

\section{Relation between Sound-Audibility and Geological Structure.}

In earthquakes which are strong enough to be recorded by seismographs, both the period and amplitude of the vibrations depend on the nature of the surface-rocks. It is therefore reasonable to suppose that some relation must exist between the audibility of the short-period vibrations and the nature

* The type of comparison is only mentioned in 13 cases in Prof. Milne's catalogue, but it is worthy of notice that 10 comparisons are made to wind, 1 to thunder, and 2 to explosions.

$\dagger$ "Observatoire National d'Athènes," Bull. Mens. Séismol. 1 année, 1896.

$\ddagger$ G. Hogben, Austral. Assoc. Rep. 1892, pp. 1-33.

§. E. Dutton, Amer. Geol. Surv., Ninth Rep. pp. 410-528.

if Wien. Geol. Jahrb. 1896, p. 523.

Phil. Mag. S. 5. Vol. 49. No. 296. Jan. 1900, E 
of the rocks in which the earthquake originates or of those on which the observers are situated. Mr. C. A. Stevenson remarks that in the Scottish earthquake of November 28, 1880 , most of the observers near the epicentre who heard the sound were stationed on hard dense rocks with little or no soil near them*. But the records of this earthquake are too few to establish a general law.

Prof. Milne's discussion of the sound-phenomena of the Japanese earthquakes is founded on a rery large number of records. In the whole country he indicates fifteen districts in which earthquakes are specially numerous, and examines the sound-phenomena with respect to its geological structure. The conclusion at which he arrives is that "generally sound is heard in rocky mountainous districts, while in the alluvial plains it is but rarely observed " $\dagger$.

The relative, rather than the absolute, frequency of soundaccompanied earthquakes being, however, the more correct test, I have calculated the percentage of the earthquakes in each district that were attended by sound and that originated under land. They are as follows:-21.6, 18.6, 1.8, 18.7, $30 \cdot 0,29 \cdot 9,23 \cdot 1,34 \cdot 5,26 \cdot 7,33 \cdot 3,8 \cdot 0,50 \cdot 9,42 \cdot 2,16 \cdot 9$, and 50.0 . Prof. Milne's general conclusion is in part supported, and in part contradicted, by this more definite evidence. On the one hand, we bave the comparatively high percentages of $42 \cdot 2$ and $34 \cdot 5$ in the mountainous districts 13 and 8 respectively. On the other, we have a percentage of 18.7 in district 4, where "the coast is rocky, built up of palæozoic strata"; while in the mountainous district 9 the percentage $(26.7)$ is practically equal to the average for the whole country $(26.5)$. The high percentage of 50 in district 15 , which consists "of a sandy coast bordering a plain," is not very reliable, as it rests on no more than eight earthquakes.

Possibly the districts are too large for the deduction of general laws. But, if we take only the rectangles, whose areas vary from 114:3 square miles in the south of the country to $92 \cdot 8$ square miles in the north, we find great variety of audibility-percentage within the limits of a district. For instance, in four consecutive rectangles $\ddagger$, bounded by the same parallels, in the Mino-Owari plain, the percentages are $14 \cdot 3,41 \cdot 0,12 \cdot 2$, and $23 \cdot 5$. Immediately to the south of the first two of these rectangles are others $\S$ in which the percentages are $77 \cdot 4$ and $11 \cdot 5$.

If, however, the audibility of an earthquake depended only

* Edinburgh Roy. Soc. Trans. vol. xi. 1881, pp. 184, 185.

+ Japan Seismol. Journ. vol. iv. 1895, pp. xviii-xix.

t 1401-1404, district 7 .

$\$ 1456$ and 1457 , district 7 . 
on the nature of the rock beneath which it originated, the percentage of audibility should not vary perceptibly at different times; and this is very far from being the case. Taking the district 7 as a whole, the percentage in November 1891 (immediately after the Mino-Owari earthquake) was $17 \cdot 9$, and during the next five months it lay between 10.5 and 12.1 ; then it suddenly rose to 38.8 in May 1892, and during the following seven months never fell below $32 \cdot 4$, while it maintained an average of 41.8 . In the smaller rectangles we find the same variety; in one (that numbered 1457), for instance, the percentage was $7 \cdot 7$ during the three months November 1891-January 1892 , and 39.0 during the next eleven months; in another (1402) the percentages during the same intervals were $10 \cdot 3$ and $55 \cdot 4$ respectively.

Thus whatever the nature of the relation between the audibility of Japanese earthquakes and the geological structure may be, it seems to be often masked by other conditions of greater importance, one of which will now be considered.

\section{Equal-Audibility Curves in the Mino. Owari District (Japan).}

The district represented in the accompanying map (fig. 2) is that part of Japan in which the Mino-Owari earthquake of 1891 and the majority of the very numerous after-shocks were most prominently felt. It is bounded by the parallels $34^{\circ} 40^{\prime}$ and $35^{\circ} 50^{\prime}$ of north latitude and by the meridians $2^{\circ} 10^{\prime}$ and $3^{\circ} 30^{\prime}$ west of Tokio. During the eight years 1885-1892 the total number of earthquakes felt in the district was 3014 , and of these 604 , or 20 per cent., were accompanied by sound. The percentage, however, varies very widely in different parts of the area in question, and the continuous curves in fig. 2 represent this variation. Dividing the whole area into 56 rectangles, the sides of which are onesixth of a degree of latitude and longitude in length, the percentage of audible earthquakes originating within each rectangle is supposed to correspond to the centre of that rectangle, and the curves are drawn in the same way as isacoustic lines. The meaning of any curve, say that marked 40, is as follows:--If any point on the curve be regarded as the centre of a small area, then 40 per cent. of the earthquakes whose centres are included within this area were accompanied by sound*.

* In constructing these curves the percentagy was regarded as zero in the rectangles where there are no epicentres, or in isolated rectangles where the number of epicentres is very small.

E 2 
The dotted lines in fig. 2 bound the area (incomplete towards the north) in which the destructive power of the earthquake was greatest; and within this area, again, the undulating line shows the path of the great fault-scarp of

Fig. 2 ,

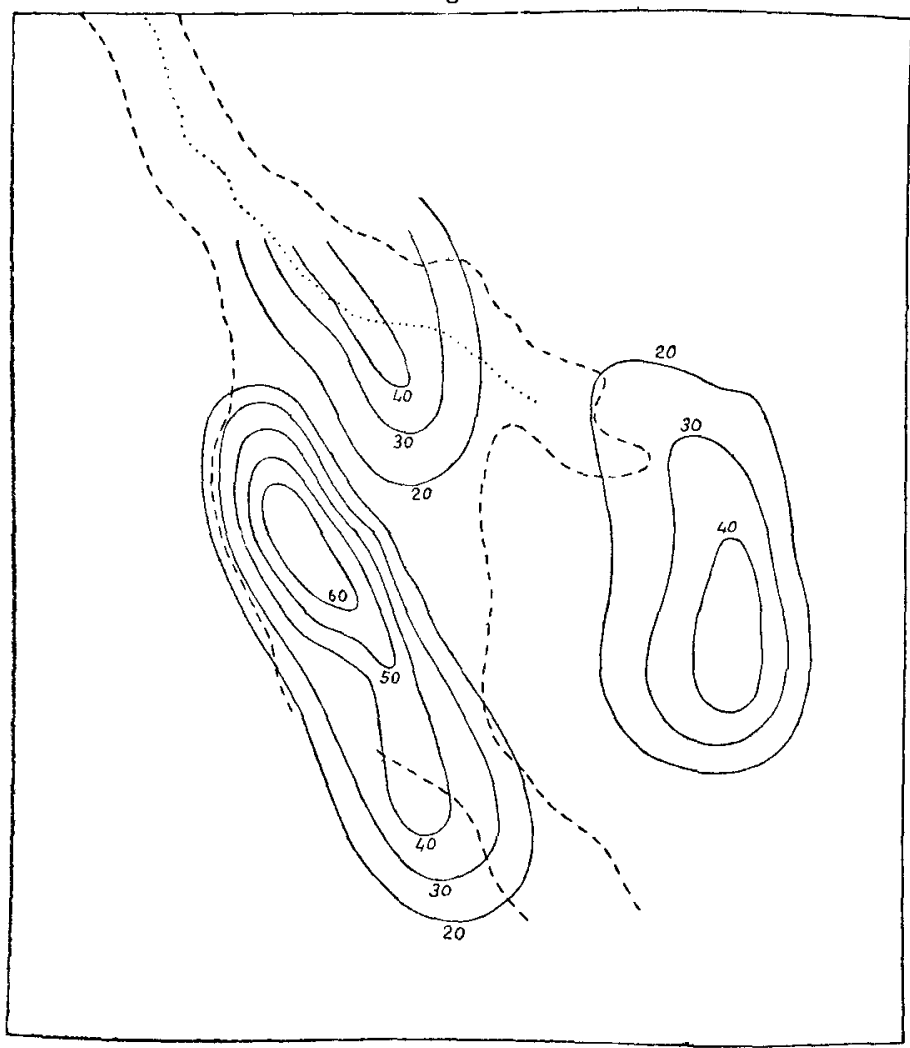

more than forty miles in length. It will be noticed that the meizoseismal area is forked, the main branch proceeding towards the south, and that the principal group of curves follows this branch. The more northerly group of curves also lies along the main meizoseismal area, while the third group of curves lies roughly in the prolongation of the easterly branch of the meizoseismal area.

It will be seen in a later section that the sound in Japanese earthquakes is only heard within a few miles from the origin. Other conditions, then, being the same, it follows that superficial earthquakes would have a greater chance of being 
audible than those which originate at a greater depth, and that the curves of highest percentages correspond to the earthquakes with the shallowest foci. It is therefore possible that the axes of the systems of curves in fig. 2 may mark out approximately the lines of growing faults.

Relation between the Intensities of the Shock and Sound.

Within and near the epicentral region of an earthquake, the intensity of the sound increases and decreases with that of the shock. Also, when the shock consists of two series of vibrations or contains two maxima of intensity, the stronger series or maximum is accompanied by the louder noise; but the difference of intensity in the case of the sound is much less pronounced than in that of the shock.

In different earthquakes, again, while the intensities of the sound and shock certainly appear to increase together, the sound which accompanies the stronger shocks is not much louder than that which attends the weaker ones at places near the epicentre. Similar terms are used in describing both : in the one case, for instance, the rumbling of a train going over a bridge only intensified a hundred times; in the other, the rumbling of thirty or forty waggons travelling at a rapid pace. Humboldt also notices that "the intensity of the hollow noise which generally accompanies an earthquake does not increase in the same degree as the force of the oscillations"*. In the Comrie earthquakes, according to one observer, "a loud noise accompanies every shock, proportionate in loudness to its strength, . . . but in the lesser ones no vibration is perceptible, merely the peculiar report is heard." Again, in October 1846 three great shocks occurred in New Zealand, and were succeeded by numerous slight tremors. "In the two last of the three grand shooks," writes Sir W. Fitzherbert, "the roaring was certainly considerable, but it was inconsiderable when compared with the concussion, whilst in the minor shocks the vibration was trifling as compared with the report" $†$.

\section{Relations between the Sound-Area and the Disturbed Area.}

Relative Magnitude of Sound-Area and Disturbed Area.The ratio which the extent of the sound-area bears to that of the disturbed area ranges continuously between the widest possible linits. At the one limit, the shock is felt but is unaccompanied by sound; at the other, the sound is heard without any attendant shock.

* Cosmos (Bohn's edition), vol. i. 1849, p. 203.

$\dagger$ Quoted by Sir. J. Hector, Austral. Assoc. Trans. vol. iii. 1891, p. 523. 
(1) The case in which no sound is heard has already been considered in discussing the inaudibility of some earthquakes ; and it is probable, as there suggested, that the absence of recorded sound is due to the defective auditory powers of the observers.

(2) In the great majority of strong and violent earthquakes, the sound-area occupies a region surrounding the epicentre, while the disturbed area extends beyond it in every direction. In Great Britain, the sound-area in our strongest earthquakes is often considerable. In the Pembroke earthquake of 1893 , the disturbed area contains about 63,600 square miles and the sound-area about 37,700 square miles, being 231 miles long and 210 miles broad. The Hereford earthquake of 1896 disturbed an area of not less than 98,000 square miles, while the sound was heard over a district 320 and 284 miles in length and breadth and abont 70,000 square miles in area. The Essex earthquake of 1884 was felt over about 50,000 square miles, and, excluding an isolated observation, the sound was heard as far as 114 miles from the centre ${ }^{*}$.

Similar materials for the earthquakes of other countries are rure. In the Verny (Turkestan) earthquake of 1887, the disturbed area is about 950 miles long, 560 miles broad, and about 400,000 square miles in area; the corresponding dimensions for the sound-area are 650 and 290 miles, and about 132,000 square miles $\dagger$. The Neapolitan earthquake of 1857 , according to Mallet, was felt over the whole Italian peninsula south of latitude $42^{\circ}$; the sound-area was confined to the neighbourhood of the epicentre, and contained only 3300 square miles $\ddagger$. Of another Italian earthquake, that of March 12, 1873, the disturbed area measures approximately 670 and 430 miles in length and breadth, and 227,000 square miles in area; excluding one isolated place (Fiume), the sound was heard over an area 236 miles long, 120 miles broad, and 22,000 square miles in area \$. In the Charleston earthquake of 1886 the sound was heard at many places more than 700 miles from the origin, and also at three places in New Hampshire more than 800 miles $\|$.

* R. Meldola and W. White, 'Report on the East Anglian Earthquake of A pril 22nd, 1884' (Macmillan, 1885).

$\dagger$ J. V. Mouchketow, 'Le Tremblement de Terre de Verny, 28 Mai (9 Juin), 1887,' Mém. du Comité Géologique (St. Pétersbourg, 1890). The above figures are obtained by measurement from the map accompanying this memoir.

† 'The Great Neapolitan Eartliquake of 1857,' vol. ii. pp. 287-288.

\$ These figures are deduced from records contained in A. Serpieri's 'Scritti di Sismologia,' parte i. 1888, pp. 44-97.

"1 C. E. Dutton, U.S.A. Geol. Surv., Annual Rep., 9th Rep. pp. 411-528. 
While the sound-area may thus attain such great dimensions in European and American earthquakes, the case is very different in those felt in Japan. When Prof. Milne remarks that "earthquake sounds only travel a few miles from their origin" *, or "the very fact that the sound ... was heard indicates . . . that those who heard the noise were not many miles removed from the origin" $\dagger$, he is referring to his experience of Japanese earthquakes in the first instance, and probably relying on it in the second. With the detailed studies on which this conclusion is founded I am not acquainted, except in one case, that of the earthquake of February 22,1880 , in which the shock was sensible for a distance of 120 miles, while sound-records come as a rule from places not more than 14 miles from the epicentre f. More decisive evidence is, however, afforded by the percentage of audibility of the Japanese submarine earthquakes. In the earthquakes which originated beneath land, during the years 1885-1892, the percentage of those accompanied by sound is, as we bave seen, 26.5. For the submarine shocks for the same period the percentage is only 0.84 , and none of the earthquakes studied originated at a greater distance than 40 or 50 miles from the shore, while the epicentres of 93 per cent. of the total number were not more than 10 miles distant.

The comparatively poor powers of the Japanese people for hearing deep sounds are of course responsible for the small dimensions of the sound-areas. The limited sound-area of the Neapolitan earthquake is perbaps due to want of observations, Mallet's inquiries having been confined principally to the epicentral region. In the Charleston earthquake, we have a large sound-area with an apparently low percentage of audibility; but the smallness of the latter quantity is probably owing to the imperfection of the records, for the percentage in the central State of South Carolina is less than in six more distant States. For the more recent British earthquakes observations are numerous, and here we have a high percentage of audibility occurring with comparatively large sound-areas.

(3) In a few earthquakes the disturbed area and soundarea practically coincide, the boundaries of both being determined by the same places of observation. The shocks are generally of moderate strength, the disturbed areas ranging from about 400 to 2000 square miles, and in one case, that of the Inverness earthquake of 1890 , to 4340 square miles.

* Japan Seismol. Journ. vol. iv. 1895, p. xviii.

+ 'Daily Telegraph,' Dec. 18, 1896.

† Japau Seismol. Soc. Trans. vol. i. pt. 2, 1880, pp. 53, 56-57, 105. 
(4) In many slight British earthaquakes the sound-area overlaps the disturbed area, as a mle only on one side, but sometimes in every direction. The Cornwall earthquake of April 1, 1898, had a disturbed area of about 175 square miles, beyond which the sound-area extended for a mile or two towards the south-west, north, and north-east (see fig. 3, p. 60). In the Comrie earthquake of July 12, 1895, the disturbed area contained only $18 \frac{1}{2}$ square miles; the sound-area overlapped its boundary by two or three miles towards the north and west, if not in all directions. The Comrie earthquake of Aug. 26, 1898, was still weaker ; the sound-area contained hut a few square miles, while the shock was only felt at one or two places within it.

(5) The limiting case, in which earth-sounds are heard without any accompanying shock, is of considerable interest. As a general rule, they appear to form part of the series of after-shocks of a great earthquake, or occur as intercalated members of a series of weak shocks. But it is possible that, under the names of barisal guns, mist-poeffers, marinas, \&c., they may also be heard quite detached from an earthquakeseries; though the identification of these mysterious noises with earth-sounds must be regarded as uncertain for the present.

Most, if not all, great earthquakes appear to include numerous earth-sounds among their attendant crowds of aftershocks, especially in and near the epicentral regions. Even in Japan, where the audibility-percentage is so low, they are far from uncommon. For instance, the 3365 after-shocks of the Mino-Owari earthiquake recorded at Gifu between Oct. 28, 1891 , and the end of 1893 , included 10 violent shocks, 97 strong, 1808 weak, 1041 feeble shocks, and 409 earthsounds*. On the other hand, in Great Britain, where the audibility-percentage is high, earth-sounds are occasionally numerous, especially at Comrie. After the strong shock of Oct. 23, 1839, one observer at Comrie noted between this date and the end of 1841,19 earthquake-shocks (10 of which are described as vertical, and 7 lateral), 25 tremors, and 234 earth-sounds $\dagger$.

It seems unnecessary to accumulate many further examples, but reference shonld be made to three cases in which earthsounds were especially numerous. In the island of Meleda, in the Adriatic Sea, earth-sounds were heard during the

* F. Omori, Journ. Coll. Sci. Imp. Univ. Japan, vol. vii. pt. 2, p. 113.

$\dagger$ J. Drummond, Phil. Mag. vol. xx., 1842, pp. 240-247. A similar series of earth-sounds followed the Comrie earthquake of March 12, 1795. 
years 1822-1826. Partsch, in his valuable memoir describing them, inserts a chronicle of the shocks and sounds observed by a resident in the island, from Nov. 17, 1824, to Feb. 18, 1826 ; from which it appears that there were during this time 30 shocks and 71 detonations. Of the shocks, all but three were accompanied by sound ; and 18 of the remaining shocks are described as "succussory," i. $e$. they consisted of a more or less vertical movement*.

The district surrounding East Haddam, in Connecticut, U.S.A., is another in which earth-sounds were at one time frequent. Before the English settlements, they were well known to the Indian inhabitants, who called the place Morehemoodus, or place of noises, and "drove a prodigious trade at worshipping the devil" there. The sounds are described in the following terms by a writer in $1729:-$ "Whether it be fire or air distressed in the subterraneous caverns of the earth, cannot be known ; for there is no eruption, no explosion perceptible, but by sounds and tremors, which sometimes are very fearful and dreadful. I havo myself heard eight or ten sounds successively, and imitating small arms, in the space of tive minutes. I have, I suppose, heard several hundreds of them within twenty years; some more, some less terrible. Sometimes we have heard them almost every day, and great numbers of them in the space of a year. Oftentimes I have observed them to be coming down from the north imitating slow thunder, until the sound came near, or right under, and then there seemed to be a breaking, like the noise of a cannon shot, or severe thunder, which shakes the houses and all that is in them." Another observer, writing about the heginning of the present, or end of the last century, says :- "The awful noises described in the preceding extract .... continue to the present time. The effects they produce are various as the intermediate degrees between the roar of a cannon and the noise of a pistol. The concussions of the earth, made at the same time, are as much diversified as the sounds in the air. The shock they give to a dwelling-house is the same as the falling of logs on the floor. The smaller shocks . . . a are spoken of as usual occurrences, and are called Moodus noises. But when they are so violent as to be heard in the adjacent houses, they are called earthquakes" $\dagger$.

* Bericht über das Detonations Phänomen auf der Insel Meleda bey Ragu:a (Wien, 1826) pp. 204-211.

t Quoted by W. T. Brigham, Boston Soc. of Nat. Hist., Mem. vol. ii. 1871 , pp. 14-16. 
Lastly, a very remarkable series of earth-sounds is that described by Humboldt as the subterranean thunder of Guanaxuato, a city on the Mexican plateau far removed from any active voleano. "The noise," he says, "began about midnight on the 9th of January, 1784, and continued for a month .... From the 13 th to the 16 th of January, it seemed to the inhabitants as if heavy clouds lay beneath their feet, from which issued alternate slow rolling sounds and short quick claps of thunder. The noise abated as gradually as it had begun. It was limited to a small space and was not heard in a basaltic district at a distance of a few miles." "Neither on the surface of the earth, nor in mines 1600 feet in depth was the slightest shock to be perceived. No similar noise had ever before been heard on the elevated table-land of Mexico, nor has this terrific phenomenon since occurred there "*.

From the above examples, and from others that might be quoted, we may infer : (1) that earth-sounds especially characterize those districts where slight shocks are frequent; (2) that in the midst of a series of earth-sounds one or more slight shocks, accompanied by precisely similar sounds, are occasionally intercalated + ; (3) that when moderate shocks are felt, the earth-sounds are heard at places where the motion is frequently vertical, and, when strong shocks are felt, at places within the epicentral districts; and (4) that in any one district, that of Comrie for example, there is a complete continuity from earthquake to earth-sound; every stage of the process is before us, from the strong earthquake in which the disturbed area extends in all directions beyond the soundarea, through the weak earthquake, in which the relations of the areas are reversed, down to the earth-sound, when the shock itself is imperceptible. We may therefore conclude that earthquakes and earth-sounds are manifestations, differing

* Cosmos (Bohn's edition), vol. i. pp. 203, 205-6.

+ It is worthy of notice that the sound in these cases is generally of short duration. For instance, the earth-sounds following the Comrie earthquake of 1839 are described by Drummond as "gas explosions." Prof. Umori also remarks (Journ. Coll. Sci. Imp. Univ. Japan, vol. vii. pt. 2, 1894, pp. 197-198) that " many of the after-shocks of the MinoOwari earthquake were attended with sounds, which were essentially of two types, being either rushing feeble noises like those caused by winds, or loud rumbling sounds like those calised by the fall of a heavy weight on the ground, or by the discharge of a gun. The sounds of the second type, which were sometimes like detonations of thunder, were most frequent and distinct in the Neo Valley [the epicentral district], where, as I believe, their origin really was. It is remarkable that tremblings of the ground accompanying these sounds were invariably rery feeble, and often not to be felt at all." 
only in degree and in the method in which we perceive them, of one and the same phenomenon.

Relative Position of Sound-Area and Disturbed Area.The excentricity of the sound-area with respect to the isoseismal lines is one of the most significant phenomena of earthquake-sounds. In weak earthquakes the sound is a more prominent feature than the shock, and it is in these that the excentricity is most easily detected; but I believe that, with a sufficiently careful study, it would be found to exist in nearly all earthquakes. Thus, in the Leicester earthquake of 1893 , which disturbed an area 58 miles long from W. $38^{\circ} \mathrm{N}$. to $\mathrm{E}, 38^{\circ} \mathrm{S}$., and 46 miles broad, the sound-area and disturbed area apparently coincided. Near the north-west end of the longer axis, however, the shock was felt, but no sound was heard, by observers at five places; while at seven places towards the opposite end, the sound was heard without any shock being sensible. It is thus clear that the isacoustic lines, if they could have been drawn, would, relatively to the isoseismals, be displaced towards the south-east.

The sound-area of the Pembroke earthquake of 1893 was bounded by a line similar in form and size to the isoseismal 4, such that, if the latter curve were shifted about ten or twelve miles in the direction of its longer axis, it would roughly coincide with the former line. In the Neapolitan earthquake of 1857 , the records collected by Mallet in his great work show that the boundary of the sound-area is similarly displaced in the direction of the longer axis of the innermost isoseismal. The peculiar form of the isacoustic lines of the Hereford earthquake of 1896 and their aberration from the isoseismal lines have been alluded to above. The observations of the Edinburgh and Lancashire earthquakes of 1889 are somewhat scanty, but they appear to indicate that the sound-areas were shifted towards the lines of the earthquake-faults*.

In the slight earthquakes of this conntry the excentricity of the sound-area is manifested by its overlapping the disturbed area in one direction. In the accompanying map ( $p .60)$ the continuous lines represent the isoseismals of intensities 3 and 4 of the Cornwall earthquake of April 1, 1898. The outer dotted line indicates roughly the boundary of the sound-area, and the inner dotted line, which is concentric with the former, separates the places where the sound was very loud from those where it was distinctly fainter. The relative positions of the isoseismals show that the earthquake-fault must hade towards the south-east, and therefore that the sound-area,

\footnotetext{
* Geol. Mag, vol. viii. 1891, pp. 64, 311.
} 
relatively to the disturbed area, is displaced towards the line of fault.

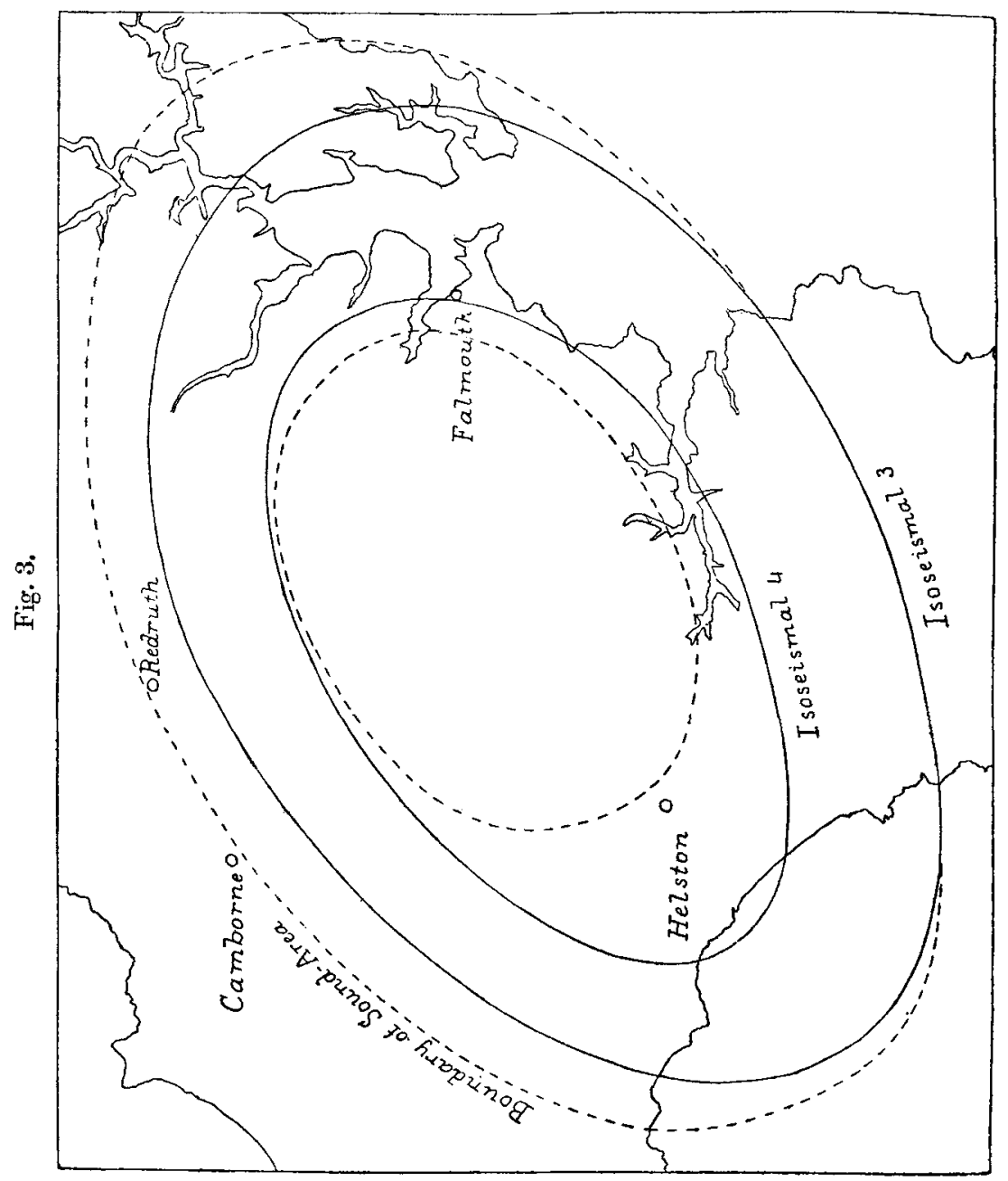

Place of Earth-Sounds in an Earthquake-Series.

In an admirable memoir, Prof. Omori has shown how the after-shocks of a great earthquake are subject to a gradual but fluctuating decline in frequency and average intensity*. $\Lambda \mathrm{t}$ first sight, it might appear that earth-sounds which, as we have seen, are merely earthquakes too weak to be felt, should be relatively more frequent towards the end of an * "On the After-Shocks of Earthquakes," Journ. Coll. Sci. Imp. Univ. Japan, vol. vii. pt. 2, pp. 111-200. 
earthquake-series. But this does not seem to be the case, so far as we can judge from the limited materials at our disposal.

The series of the Mino-Owari after-shocks recorded at Gifu is the most valuable and complete of any so far published. Prof. Omori gives the number of earthquakes for every day from Oct. 28,1891, to Dec. 31, 1893, classifying them under the heads violent shocks, strong shocks, weak shocks, feeblo shocks, and sounds. From this cataloguo the curves in fig. 4 have bren constructed. Those for the violent and

Fig. 4.

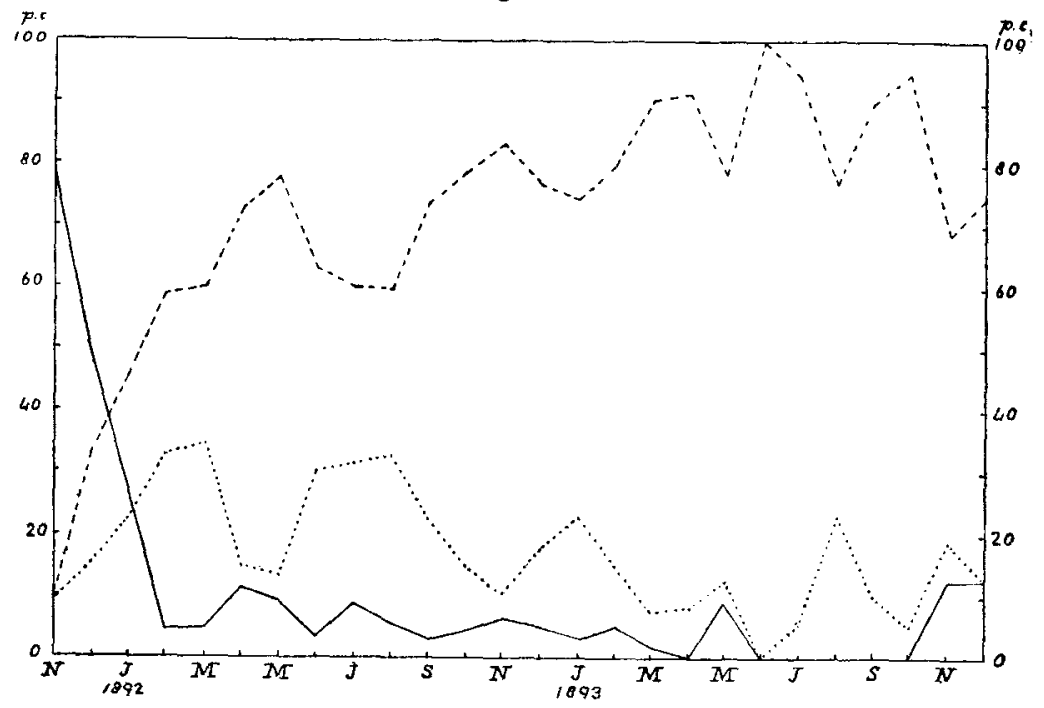

strong shocks have been omitted, on account of their numerical inferiority. The three curves, continuous, broken, and dotted, represent respectively the percentages (with regard to the total number of earthquakes each month) of the weak shocks, feeble shocks, and sounds, beginning in Nov. 1891. During the first three months, the weak shocks rapidly decline in relative frequency, while there is a corresponding increase in that of both feeble shocks and sounds. But, at the end of five months, the two latter curves begin to diverge, the feeble shocks being subject to a fluctuating increase, and the sounds to a fluctuating decrease, in relative frequency.

Very similar, though less exact, is the evidence furnished by Drummond's Comrie record from Oct. 1839 to Dec. 1841, the principal shock being that which occurred on Oct. 23, $1839^{*}$. In this series the earth-sounds greatly predominated,

*. Phil. Mfag. vol, xx. 1842, pp. 240-247. 
there being 276 earth-sounds and only 54 shocks and tremors. If we divide the whole time into nine intervals of three months each, the percentages of earth-sounds in the several intervals are $87,89,88,100,95,80,50,76$, and 50 ; showing that towards the close of the period considered, the perceptible shocks increased in relative frequency.

Time-Relations of the Sound and Shock.

In earthquake-catalogues, the time-relations of the sound and shock are not often recorded ; and it is therefore probable that such entries, when they do occur, refer to the more prominent relations. In Mallet's great catalogue, for instance, the time-relations are given for only 423 earthquakes ; and in these the sound is said to have preceded the shock in 100 cases, accompanied it in 307 , followed it in 9, preceded and accompanied it in 2, accompanied and followed it in 2, and preceded, accompanied, and followed it in 3 cases. Thus, either the sound occurred more frequently before the shock than after, or the sound which preceded the shock was louder and more readily observed than that which followed.

In studying the more recent British earthquakes, I have endeavoured to attain greater precision in defining the timerelations of the three principal epochs of the sound and shock, namely, the beginning, epoch of maximum intensity, and the end. In the Table which follows, the letters $p, c$, and $f$ indicate the number of records in which any epoch of the sound preceded, coincided with, and followed the corresponding epoch of the shock. The first five shocks were all weak.

TABLE VI.

\begin{tabular}{|c|c|c|c|c|c|c|c|c|c|}
\hline \multirow{2}{*}{ Earthquale. } & \multicolumn{3}{|c|}{ Beginuing. } & \multicolumn{3}{|c|}{$\begin{array}{l}\text { Epoch of } \\
\text { Maximum } \\
\text { Intensity. }\end{array}$} & \multicolumn{3}{|c|}{ End. } \\
\hline & $p$. & $c$. & $f$. & $p$ & $c$. & $f$ & $p$ & $c$. & $f$. \\
\hline Cornwall, 1892. & 12 & 3 & 1 & ... & & $\ldots$ & 1 & 5 & 8 \\
\hline,$\quad 1895$ & 1 & 4 & $\ldots$ & $\ldots$ & 1 & $\ldots$ & $\ldots$ & 2 & 1 \\
\hline 1896. & 4 & ... & ... & $\ldots$ & & $\ldots$ & $\ldots$ & 1 & ... \\
\hline$" \quad 1898$. & $\mathbf{5}$ & 4 & $\ldots$ & $\ldots$ & 2 & $\ldots$ & $\ldots$ & 4 & $\dddot{2}$ \\
\hline Exmoor, 1894 & 9 & & 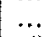 & & 6 & 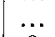 & & 1 & 4 \\
\hline Leicester, 1893 ................. & 59 & 11 & 3 & 19 & 18 & 3 & 16 & 6 & 16 \\
\hline Pembroke, 1892 ............. & 84 & 35 & 13 & 19 & 56 & 5 & 14 & 17 & 73 \\
\hline , $\quad 1893 \ldots$ & 80 & $16^{2}$ & 15 & 9 & 32 & 9 & 7 & 11 & 55 \\
\hline Hereford, $1896 \ldots \ldots \ldots \ldots \ldots$ & 503 & 71 & 39 & 25 & 85 & 7 & 72 & 88 & 161 \\
\hline $\begin{array}{l}\text { Percentage for each epoch, } \\
\text { weaker shocks }\end{array}$ & $72 \cdot 1$ & $95-6$ & 0.3 & & 1000 & & 3.5 & 44.8 & $51 \cdot 7$ \\
\hline Ditto, stronger shocks ............ & 781 & $14: 3$ & $7 \cdot 5$ & $25 \cdot 1$ & $66 \cdot 6$ & 84 & $20 \cdot 3$ & $22 \cdot 8$ & 569 \\
\hline
\end{tabular}


Thus, as a general rule, the beginning of the sound precedes that of the shock, but occasionally coincides with it, especially when the earthquake is weak. For weak shocks the epochs of maximum intensity of both always coincide; while, for stronger shocks, the epoch of maximum intensity of the sound generally coincides with, but sometimes precedes, that of the shock. The end of the sound hardly ever precedes, but often coincides with, that of the shock in weak earthquakes, and in both strong and weak earthquakes more frequently follows it than otherwise.

Time-Relations with regard to Distance from the Epicentre.The great majority of the records are from places not far from the epicentre. The effect of distance on the time-relations is shown more clearly in the next Table (p. 64), in which the number of observations is given for each epoch and district; but for convenience of comparison the figures in the other columns are percentages of the numbers of observations. This Table of necessity refers only to the stronger earthquakes.

It appears, then, that the beginning of the sound generally precedes that of the shock in all parts of the sound-areas, even close to the epicentre.

The epochs of maximum intensity of the sound and shock coincide, as a rule, especially in the central counties and outer ring; but in the inner ring of counties observations of precedence increase in frequency. In the case of the Hereford earthquake, an unalysis of the observations according to direction, though it rests on a small number of records, indicates that the percentage of observations of coincidence undergoes a marked decrease in the inner ring in the counties traversed by the longer axis of the isoseismal lines, while in those which lie along the shorter axis it is nearly constant. The much weaker Leicester earthquake of 1893 leads to a somewhat similar conclusion. The epoch of maximum intensity of the sound preceded that of the shock at 19 places, which are, as a rule, near the ends of the longer axis of the disturbed area ; and coincided with it at 18 places, which are not far distant from the epicentre or shorter axis, and in two cases close to the ends of that axis.

In the Pembroke earthquake of 1892 , the end of the sound generally followed that of the shock all over the disturbed area; in that of 189. , observations of coincidence increase with the distance from the origin. On the whole, the percentages for this epoch in the Hereford earthquake do not vary much with the distance. In the Leicester earthquake of 1893 the end of the sound preceded that of the sbock at 16 places generally near the longer axis of the disturbed area, and 
64

Dr. C. Davison on Earthquake-Sounds.

\begin{tabular}{|c|c|c|c|c|c|c|c|c|c|c|c|c|}
\hline \multirow{4}{*}{ 总 } & $\dot{r}$ & E & $\infty 5$ & 府 & \$ & $\overrightarrow{10}$ & & $\overrightarrow{10} \quad \mathscr{\sigma}$ & & 5 & 8 & 鬲 \\
\hline & $\circ$ & L & $\cong=$ & 8 & $\mathscr{A}$ & 莳 & 芩 & 蒲 & $\approx$ & $\vec{\infty}$ & $\infty$ & ลิ \\
\hline & $\dot{2}$ & $\infty \quad \infty \underset{H}{H}$ & $a \cong$ & $\Rightarrow$ & a & $\pi$ & ริ & 芯 晑 & ๙ิ & $\vec{\infty}$ & 3 & 占 \\
\hline & ف요 & $\mathbb{R} I$ & 周 0 & $\stackrel{\infty}{\sim}$ & 里 & 웡 & te & $\vec{\forall} \stackrel{9}{9}$ & $\ddot{2}$ & พิ & 8 & $\infty$ \\
\hline \multirow{4}{*}{ 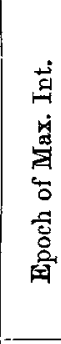 } & 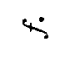 & $\infty \quad \infty \quad$ & $\therefore$ 아 & 0 & $\infty$ & $\Rightarrow$ & 今ั & $\vdots=$ & & $\vdots$ & 8 & 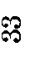 \\
\hline & 0 & $0 \sqrt{5}$ & 88 & 5 & $\mathbb{2}$ & H & $\stackrel{\infty}{1}$ & $\vec{\sigma}=$ & $\ddot{\infty}$ & 5 & 8 & 5 \\
\hline & $\dot{2}$ & 0 & $\approx 0$ & $\stackrel{m}{q}$ & $\stackrel{9}{\rightarrow}$ & $\exists$ & $\vdots$ & $\infty 5$ & $\vdots$ & $\ddot{~}$ & s & $\vdots$ \\
\hline & $\begin{array}{l}\tilde{8} \\
\dot{3} \\
\dot{z}\end{array}$ & 요 0 & 아 & 5 & ๑ิ & $\stackrel{\infty}{\sim}$ & $\stackrel{\infty}{=}$ & สิ 0 & - & 19 & 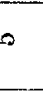 & $\infty$ \\
\hline \multirow{4}{*}{ 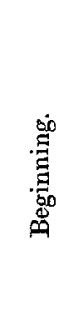 } & 3 & $0-\infty$ & $\cong$ & 9 & 10 & N & $\sigma$ & $\forall \quad \infty$ & $\sharp$ & $\sim$ & $\infty$ & $\Rightarrow$ \\
\hline & $\dot{0}$ & $\frac{19}{+1}=F$ & $\stackrel{7}{\approx}$ & ล & $\Rightarrow$ & $\stackrel{9}{\rightarrow}$ & 0 & ㅇำ & $\#$ & 0 & $\infty$ & $s$ \\
\hline & $\dot{z}$ & $\mathscr{F} \stackrel{\infty}{\infty}$ & 용 & 8 & म & 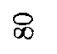 & 8 & 8 & 29 & $\$$ & 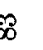 & $\stackrel{\infty}{\infty}$ \\
\hline & 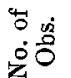 & 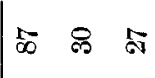 & 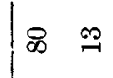 & 8 & 孚 & $\stackrel{50}{2}$ & $\ddot{g}$ & $\widehat{c}$ & ริ & & 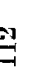 & 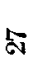 \\
\hline
\end{tabular}

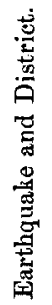
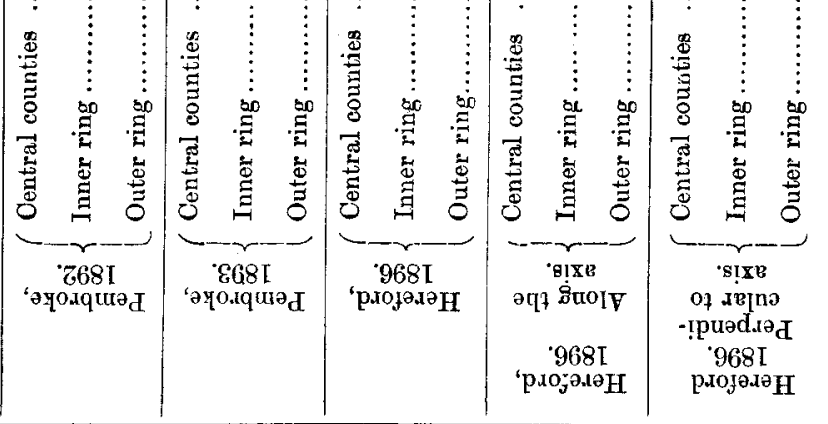
especially close to the ends of it ; and it followed it at $\mathbf{1 6}$ places chiefly near the epicentre or the shorter axis.

Apparent Outracing of the Shock by the Sound.-The partial coincidence of the sound with the shock at places near the epicentre, and its precedence at others more distant, have led some seismologists to believe that the sound-vibrations travel with a greater velocity than those which constitute the perceptible shock*. From the evidence of British earthquakes we may conclude that the difference in velocity, if it exist, is very slight; for, otherwise, the sound could not be heard after the shock at places so far distant as 180 miles from the epicentre $\dagger$.

In the earthquakes of some other countries it would seem that the sound generally ceases before the shock, and often before the shock begins. In such cases there is clearly at least an apparent outracing of the shock by the sound; but it is not improbable that this is due merely to the defective powers of the observers for bearing the weak sound which follows the shock.

Relative Duration of the Sound and Shock.-When the timerelations of both beginning and end of the sound and shock are noted by observers, it is generally possible to determine their relative duration. The figures in the following table give the number of records in which the duration of the sound is greater than, equal to, or less than that of the shock, as well as the number in which the relative duration is doubtful.

The most important figures in Table VIII. (p. 66) are those which give the duration of the sound as greater or less than that of the shock. Those which make the duration of both equal are not entitled to the same consideration; for the statement that the sound and shock were coincident at both ends is less precise than the others. We may therefore conclude that the duration of the sound is generally greater than that of the shock.

* For instance, J. Drummond, Phil. Mag. vol. xx. (1842) p. 240; E. J. Lowe, Proc. British Meteor. Soc. vol. ii. (1865) p. 55; H. J' Johnston-Lavis, Geol. Mag. vol. ix. (1892) pp. 280-281; T. 'Taramelli and G. Mercalli, $R$. Accad. dei Lincei, Memorie, \&c., vol. iii. (188j) p. 55, and Annali dell' Uff. Centr. di Meteor. e Geod. vol, viii. (1888), parte iv.; M. Baratta, ibid. vol, iii. (1889) parte iji.

+ As at Baltinglass (co. Wicklow) in the Hereford earthquake of 1896.

Plil. Mag. S. 5. Vol. 49. No. 296. Jan. 1900. 
TABLE VIII.

\begin{tabular}{|c|c|c|c|c|}
\hline \multirow{2}{*}{ Eartlsquake. } & \multicolumn{4}{|c|}{$\begin{array}{c}\text { Duration of Soind with relerence to that } \\
\text { of Shuek. }\end{array}$} \\
\hline & Greater. & Equal. & Less. & Doubtful. \\
\hline Cornwall, $1892 \ldots .$. & 5 & 1 & $\ldots$ & 1 \\
\hline . $\quad 1898 \ldots \ldots$ & 2 & 3 & $\ldots$ & $\ldots$ \\
\hline Exmoor, $1894 \quad \ldots$. & 5 & $\cdots$ & $\cdots$ & $\ldots$ \\
\hline Leicester, $1893 \ldots$. & 22 & 8 & 1 & 6 \\
\hline Pembroke, $1892 \ldots .$. & 69 & 11 & 4 & 8 \\
\hline,$\quad 1893 \ldots$. & 49 & 11 & 4 & 6 \\
\hline Herefurd, $1896 \ldots .$. & 86 & 40 & 12 & 63 \\
\hline 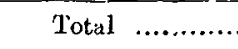 & 238 & 74 & 21 & 84 \\
\hline Percentage ...... & 57 & 18 & 5 & 20 \\
\hline
\end{tabular}

Origin of Earthruake-Sounds.

In any earthquake there are generally thres well-defined stages of motion-the preliminary tremor, the principal portion; and the end portion. In the first, the charracteristic movements are small in amplitude and short in period; the second and most active part of the disturbance consists chiefly of vibrations of larger anjplitude and longer period; and these are followed by the feeble movements which constitute the end portion. Slow undulations, with a period of about one-half to two seconds, may, however, be present in all three stages; while the ripples, with a period of one-tenth of a second or more, may be superposed on the slow undulations in the second and third stages as well as in the first. The average period of the ripples, it is important to notice, is slightly greater during the principal portion than during the other two stages*.

During the earlier part of the movement there is a distinct increase in the period of the ribrations; and this has led some seismologists $\dagger$ (all at the time living in Japan) to suggest

" See a valuable papex by F. Omori and K. Hirata, "Earthquate Measurement at Miyako," Joum. Coll. Sci, Imp. Univ, Tokyo, vol. xi. (1899) pp. 161-195.

† J. A. Ewing, "Earthquake Measurement," Mem. of the Sci. Department, Univ. of 'Tokio, No. 9 (1883), p. 11 ; J. Nilne, Japan. Seismol. Soc. Trans. vol. xii. (1888) pp. 58-09 ; F. Omori, Journ. Sci. Coll. Imp. Univ., Tokyo, vol. xi..(1890) p. 147. 
that the first recorded tremors may be the successors of those which produce the preliminary earthquake-sound. The observations of British earthquakes show, however, that the sound-vibrations are not confined to the earlier stage, but that, like the ripples, they are also superposed on the slow undulations which form the main feature of the principal and end portions of an earthquake.

Some of the phenomena of earthquake-sounds, as we have seen, are due to the neighbourbood of the sound to the varying lower limit of audibility. There are others, such as the timeand space-relations of the sound and shock, tor which a different explanation is required, and whose origin is of a geological rather than a physical character.

The theory which follows is based on the supposition that the majority of non-volcanic earthquakes are due to the gradual, but intermittent, growth of faults; the immediate cause of the disturbance being the friction produced by the slipping and rubbing of one of the adjoining rock-masses over and against the other* ${ }^{*}$.

A fault-slip does not of neressity take place concurrently all over the focus or instantaneously at any one point of it. But, as a general rule, it certainly occupies a very short interval of time, and at places near the epicentre the duration of the sensible part of an earthquake must be mainly due to the size of the focus and the finite velocity of the earthwaves.

The seismic focus is practically a surface inclined to the horizon, and is often of great length in a horizontal direction. In its simplest form there will be a central region of the faultsurface where the relative displacement of the two rock-masses is a maximum, and this will be surrounded by a region in which the relative displacement is small, and gradually dies away towards the edges. As the vibrations of great amplitude are also of long period, we may consider that from all parts of the focus there start together vibrations of various amplitude and period, the large and slow undulations coming mostly from the central region, and the small and rapid vibrations from those which bound it. It is, I believe, from these

* The principal facts in favour of the fault-slip theory are:-(1) The elongated forms of the isoseismal lines, the longer axes of which in any district are, as a rule, either parallel or perpendicular to one another, and parallel, or nearly so, to the chief lines of fault; (2) the formation of fault-scarps concurrently with violent earthquakes; (3) the impossibility of a great fault growing otherwise than by an almost intiuite nuuber of slips ; and (4) the enormous excess of the number of earthquakes over the number of faults in any one district. 
marginal regions, and especially from the upper and lateral margins, that the more sensible sound-vibrations chiefly come. I will now endeavour to show how the phenomena of earthquake-sounds can be explained on this theory.

If there is no discontinuity in period between the large vibrations which come from the centre of the area and the sound-vibrations from the focal margius, it is evident that among the vibrations must be included those which produce the deepest sonnd that can be heard by the human earr. The rumbling character of the sound may be due partly to its neighbourhood to the lower limit of audibility, partly, no doubt, to irregularities in the fault-surfaco producing local variations in the initial disturbance. To the latter cause may also be owing the intermittent sounds heard by some observers.

But whether there be any slight fluctuations in amplitude and period, or not, it is evident that the average intensity of tho sound must gradually increase until the shock is felt; and as soon as it is over, or nearly over, must gradually die away. At the same time the greater amplitude of the vibrations from near the central part of the focus will render audible vibrations of longer period than those which come from the margins; and thus the depth of the sound will increase and decrease with the intensities of the sound and shock. Especially will this be the case with the vibrations from the neighbourhood of that part of the focus where the initial amplitude is greatest; and the strongest vibrations and loud explosive crashes audible to some persons should therefore be observed concurrently.

Similar reasoning leads to the conclusion that the intensity of the sound should increase with that of the shock in different earthquakes, and that the sound should be deeper with strong shocks than with weak ones. But while the marginal vibrations are limited in period and amplitude, those from the central parts of the focus bave a much wider range. With very weak shocks the sound should be the most prominent feature; with very strong ones the sound, though actually louder, should be relatively insignificant; and when, as in the Hereford earthquake, the earthquake consists of two distinct parts, the two shocks may differ widely in intensity, while the accompanying sounds may be almost equally loud.

With observers of given average auditory powers, the magnitude of the sound-area depends on the limited strength of the marginal vibrations, and on the dimensions of the seismic focus, and therefore of its marginal regions. The magnitude of the disturbed area depends partly on the size of the focus, 
chiefly perhaps on the initial intensity of the vibrations from its central portion. While the dimensions of the sound-area should generally increase with those of the disturbed area, it is evident that they should not increase in the same ratio. With very strong shocks, the sound-area should be a comparatively small district surrounding the epicentre. With very slight ones, the marginal regions would be so great compared with the central portion of the focus, that the sound-area might overlap the disturbed area. In the limit, the central portion of the focus would vanish, and an earth-sound would be the only result sensible to human beings*.

Several of the phenomena of earthquake-sounds depend on the superficial form and inclined position of the focus, and on the fact that the most sensible sound-vibrations come from the upper and lateral margins. The isacoustic lines and the boundary of the sound-area should not be concentric with the isoseismal lines. Relatively to the latter the sound-area will be shifted towards the fault-line, and also in a direction parallel to it, if one lateral margin should predominate over the other.

The time-relations of the sound and shock remain to be considered. The sound-vibrations from the margin nearest to the observer should be heard before the shock begins, those from the upper margin, and possibly from parts of the central portion, during the progress of the shock, and those from the furthest margin after the shock ends. Moreover, the soundvibrations from the nearer lateral margin will be of greater intensity than those from the further one; and thus the foresound should be more generally heard than the after-sound, and with Japanese and some other observers should be the only one perceptible. The percentage of observations of the after-sound should also diminish with the increasing distance from the origin; and the duration of the sound, especially near the epicentre, should be greater than that of the shock.

At places near the epicentre, and also at places whose distances are great compared with the dimensions of the focus, the sound-vibrations which appear loudest will be those which originate near the central portions of the focus; and thus the epochs of maximum intensity of the sound and shock should coincide. If, however, the horizontal length of the nearer focal margin be considerable, the sound which seems loudest to observers at a moderate distince may come from or

* It has been suggested that the comparative smallness of the soundarea may be due to the more rapid extinction of the sound-vibrations; but the explanation is clearly incomplete, for it fails in the cases in which the sound-area overlaps the disturbed area. 
near that margin ; for there is but little change in the initial intensity of the sound-vibrations from the neighbourhood of the central portion. To observers who are situated near the continuation of the line of fault, the maximum epoch of the sound will therefore precede that of the shock; while to those who are near the minor axis of the isoseismals, the two epochs will approximately coincide.

IV. Contact Electricity. By Frederick S. Spiers, B.Sc., A.C.G.I.*

$\S 1 . T \mathrm{TE}$ object of this investigation was to determine, in a more satisfactory manner than has hitherto been attempted, the part that the medium plays in the P.D. that is observed between two dissimilar metals when they are metallically connected. No experiment on this important point, whether made in vacuo or in any gas whatsoever, can be considered decisive unless the films of air condensed on the two plates of metal be first removed. If the Volta effect is due to the air at all, it is most certainly due to that part of the atmosphere immediately surrounding the metals, namely, to the condensed surface-layers of air or oxygen ; and hence it is in the highest degree essential to be certain of the entire removal of this surface-layer before any experiments can be considered decisive. The molecular attraction between a metal and the gaseous film in close contact with it is probably of very considerable magnitude; hence it is useless simply to surround the metals with another gas, and then assume that your measurements are being mide in that second gas, ignoring the original condensed sheet of air.

Most experimenters on the subject have either ignored altogether or else failed to realize in full the presence and possible astion of these air-sheets condensed on the metals. A critical and, I may add, wholly delightful account of the work done prior to the year 1884 is to be found in the exhaustive report presented by Prof. Oliver Lodge to the British Association in that year. Nobody will venture to claim finality for any experiment bearing on the subject that is described in that report. Neither can it be said that any work published since that date effectually and decisively clears up the many doubts and difficulties with which this matter bristles. There are, however, two important researches concerning which a few remarks here would not be out of place.

* Communicated by the Physical Suciety : read Nov. 10th, 1899. 